\title{
Potential benefits of melatonin in organ transplantation: a review
}

\author{
Eduardo Esteban-Zubero', Francisco Agustín García-Gil2, Laura López-Pingarrón³, \\ Moisés Alejandro Alatorre-Jiménez ${ }^{4}$, Pablo Iñigo-Gil33, Dun-Xian Tan ${ }^{4}$, \\ José Joaquín García' and Russel J Reiter ${ }^{4}$
}

1Department of Pharmacology and Physiology, University of Zaragoza, Zaragoza, Spain 2Department of Surgery, Gynaecology and Obstetrics, University of Zaragoza, Zaragoza, Spain 3Department of Medicine, Psychiatry and Dermatology, University of Zaragoza, Zaragoza, Spain ${ }^{4}$ Department of Cellular and Structural Biology, University of Texas Health Science Center at San Antonio, San Antonio, Texas, USA

\begin{abstract}
Organ transplantation is a useful therapeutic tool for patients with end-stage organ failure; however, graft rejection is a major obstacle in terms of a successful treatment. Rejection is usually a consequence of a complex immunological and nonimmunological antigen-independent cascade of events, including free radical-mediated ischemiareperfusion injury (IRI). To reduce the frequency of this outcome, continuing improvements in the efficacy of antirejection drugs are a top priority to enhance the long-term survival of transplant recipients. Melatonin ( $\mathrm{N}$-acetyl-5-methoxytryptamine) is a powerful antioxidant and ant-inflammatory agent synthesized from the essential amino acid L-tryptophan; it is produced by the pineal gland as well as by many other organs including ovary, testes, bone marrow, gut, placenta, and liver. Melatonin has proven to be a potentially useful therapeutic tool in the reduction of graft rejection. Its benefits are based on its direct actions as a free radical scavenger as well as its indirect antioxidative actions in the stimulation of the cellular antioxidant defense system. Moreover, it has significant anti-inflammatory activity. Melatonin has been found to improve the beneficial effects of preservation fluids when they are enriched with the indoleamine. This article reviews the experimental evidence that melatonin is useful in reducing graft failure, especially in cardiac, bone, otolaryngology, ovarian, testicular, lung, pancreas, kidney, and liver transplantation.
\end{abstract}

Correspondence should be addressed to E Esteban-Zubero or R J Reiter Email eezubero@gmail.com or reiter@uthscsa.edu

\section{Introduction}

Organ transplantation is a useful therapeutic tool for patients with end-stage organ failure. Surgery, drugs, and knowledge innovations may possibly improve results allowing this procedure to be used for other organs. According to World Health Organization (WHO), 114,690 transplants were performed worldwide in 2012, 1.8\% more than in 2011, but still less than $10 \%$ of the global needs. Kidney (68\%) and liver (21\%) are the most frequently transplanted organs, and

\author{
Key Words \\ - melatonin \\ - organ transplantation \\ - graft failure \\ - ischemia-reperfusion injury \\ - preservation fluids
}

more of them are from deceased donors (58\% kidney and 82\% liver) (http://www.transplant-observatory.org accessed 24 September 2015). Continuing improvements in the efficacy of antirejection drugs have greatly contributed toward prolonging the long-term survival of transplant recipients; however, the 5-year survival following transplantation remains low (90\% for renal, 75\% for heart, 72\% for liver, 55\% for lung, and only 50\% for heart-lung) (Fildes et al. 2009).

Published by Bioscientifica Ltd 
Moreover, lifelong use of immunosuppressive drugs increases the risk of opportunistic diseases and malignancies. About $20 \%$ of transplanted patients have a diagnosis of cancer after 10 years of continued immunosuppressive therapies, a risk two- to five-fold higher than that of the general population (Vajdic et al. 2006).

Complex immunological and nonimmunological problems accompany organ graft failure. A nonimmunological antigen-independent cascade of events is produced by ischemia-reperfusion injury (IRI). IRI is a pathological condition characterized by an initial restriction of blood supply to an organ followed by the restoration of perfusion, which involves oxidative stress that arises from the imbalance between free radical overproduction and insufficient antioxidant defense (Witzigmann et al. 2003, Land 2005). This process leads to cell death through the activation of several pathways (Selzner \& Clavien 2001, Yellon \& Hausenloy 2007, Ben Mosbah et al. 2010).

Melatonin ( $\mathrm{N}$-acetyl-5-methoxytryptamine) is a powerful antioxidant (Tan et al. 1993, Rodriguez et al. 2004, Zhang \& Zhang 2014, Galano et al. 2015, Manchester et al. 2015) produced by the pineal gland as well as by many other organs including ovary, testes, bone marrow, gut, placenta and liver (Tan et al. 1999, Venegas et al. 2012, Acuña-Castroviejo et al. 2014, Reiter et al. 2014). It is synthesized from the essential amino acid L-tryptophan in a process mediated by the action of four enzymes: tryptophan hydroxylase, L-aromatic amino acid decarboxylase, $\mathrm{N}$-acetyltransferase, and acetylserotonin methyltransferase (Singh \& Jadhav 2014). Melatonin is a biological rhythm regulator and has a variety of other essential functions (Hardeland et al. 2009, Reiter et al. 2009a, 2013, Maria \& Witt-Enderby 2014, Romero et al. 2014, Coelho et al. 2015, Vriend \& Reiter 2015).

A strong immunogenic stimulus of an allogeneic solid organ transplant does not modulate the endogenous patterns of melatonin secretion (Cardell et al. 2008). For this and other reasons, and the fact that melatonin supplementation is considered safe, without reported adverse events (Buscemi et al. 2006), we suggest that melatonin would have beneficial effects in organ transplantation. We initially explain the graft rejection processes and thereafter provide the rationale for the proposed use of melatonin.

\section{Ischemia-reperfusion injury}

Cold ischemia causes parenchymal cell death as a consequence of widespread cellular metabolic disturbances resulting from glycogen consumption, lack of adequate oxygen supply, ATP depletion, and degradation of ATP into its metabolites (adenosine, inosine, and hypoxanthine), the conversion of xanthine oxidase by xanthine dehydrogenase, and reduced intracellular $\mathrm{pH}$ (Teoh \& Farrell 2003, Zhai et al. 2011). The decrease in $\mathrm{pH}$ levels is accompanied by lowered mitochondrial oxidative phosphorylation (Kanoria et al. 2012). There is also reduced vascular perfusion, which is caused by endothelial swelling, intravascular hemoconcentration, and an imbalance between the vasoactive mediators endothelin (ET) and nitric oxide (NO.) (Kukan \& Haddad 2001, Scheinichen et al. 2003, Ramalho et al. 2006).

Reperfusion injury involves both direct and indirect cytotoxic mechanisms including an inflammatory immune response with the release of inflammatory mediators; interleukins (ILs) and TNF- $\alpha$ cause oxidative stress injury and recruitment of leukocytes (Lutz et al. 2010, Zhai et al. 2011). These processes are summarized in Fig. 1. In addition, during vascular reperfusion, ATP metabolites are produced with increases in reactive oxygen species (ROS) levels including superoxide radical $\left(\mathrm{O}_{2} \cdot-\right)$, hydrogen peroxide $\left(\mathrm{H}_{2} \mathrm{O}_{2}\right)$, and the hydroxyl radical (.OH) (Boros \& Bromberg 2006, Huang et al. 2007). The $\cdot \mathrm{OH}$, which is produced due a reductive cleavage of $\mathrm{H}_{2} \mathrm{O}_{2}$ by $\mathrm{Fe}^{2+}$ or $\mathrm{Cu}^{2+}$, initiates the process of lipid peroxidation (LPO), this process consists of a radical chain reaction that leads to the destruction of polyunsaturated fatty acids. LPO disrupts normal fluidity and permeability of cell membranes causing cell edema, massive overload of $\mathrm{Ca}^{2+}$ and $\mathrm{Na}^{+}$, and cell lysis (Korkmaz et al. 2009, Negre-Salvayre et al. 2010). Malondialdehyde (MDA) and 4-hydroxynonenal (4-HNE) are produced during LPO and are indicators of ROS-dependent tissue damage. MDA promotes the

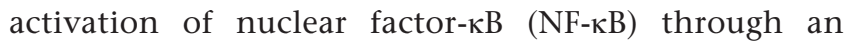
inflammatory process, which regulates the expression of proinflammatory cytokines. 4 -HNE is a chemoattractant for neutrophils (Jaeschke 1996).

During LPO, mitochondrial membrane permeability is increased due to a loss of mitochondrial integrity. This occurs as a result of the depletion of ATP levels and a rise in cellular $\mathrm{Ca}^{2+}$ concentrations, which promote an overload in mitochondrial $\mathrm{Ca}^{2+}$. This dysfunction results in the release of cytochrome $c$ into the cytoplasm, subsequent activation of caspase activity, and initiation of apoptotic cell death (Crompton 1999). Changes in the permeability at mitochondrial membrane are mediated via activated pro-apoptotic members of the BCL2 family of proteins, including BAX or BAK (Reed 1994), or it is

Published by Bioscientifica Ltd 
secondary to mitochondrial permeability transition pore (MPTP) opening (Baines et al. 2005, Green 2005).

NO is generated by three different synthase isoforms (NOS): endothelial (eNOS), neuronal (nNOS), and inducible synthase (iNOS); each utilizes L-arginine and produces NO. and L-citrulline (Hines et al. 2002, Hsu et al. 2002). During IRI, diminished NO- levels are due to both decreased production and increased scavenging of NO- by elevated levels of ROS. This is important because $\mathrm{NO}$ modulates the intensity of the IRI by regulating neutrophil adhesion and platelet aggregation (Serracino-Inglott et al. 2001). During IRI, endothelial dysfunction occurs including a reduction in eNOS function due to a direct action and the elaboration of the endogenous competitive inhibitors (asymmetric dimethylarginine, ADMA), the increased coupling of $\mathrm{NO} \cdot$ with $\mathrm{O}_{2} \cdot-$ (which generates the peroxynitrite anion, $\mathrm{ONOO}^{--}$a nonradical reactant which is equally toxic as $\cdot \mathrm{OH}$ ) and cell-free hemoglobin, and the oxidation of target soluble guanylyl cyclase, a molecular target of NO. (Li et al. 2014).

Melatonin greatly limits IRI based on its direct actions as a free radical scavenger as well as its indirect antioxidative actions in the stimulation of the cellular antioxidant defense system, that is, by increasing mRNA levels and activities of several important antioxidant enzymes (Barlow-Walden et al. 1995, Pablos et al. 1998); these include superoxide dismutase (SOD, which catalyzes the conversion of $\mathrm{O}_{2} \cdot-$ to $\mathrm{H}_{2} \mathrm{O}_{2}$ ), glutathione peroxidase (GPx), glutathione reductase (GRd), and glutamylcysteine ligase, which promotes the synthesis of another important intracellular antioxidant, glutathione (GSH) (Reiter et al. 2000, Rodríguez et al. 2004, Hardeland 2005). In addition to directly scavenging several ROS and reactive nitrogen species (RNS), which are generated during IRI (Korkmaz et al. 2009, Reiter et al. 2010), it reduces myeloperoxidase (MPO) activity (Lee et al. 2002). Numerous studies have provided data showing that melatonin protects against the IRI-induced impairment of mitochondrial respiration, ATP synthesis, mitochondrial swelling, and LPO (Okatani et al. 2003, Kireev et al. 2013). Melatonin also reduces electron leakage from the respiratory chain that limits free radical generation and increases the expression of uncoupling protein, which is thought to improve electron flow through the respiratory chain and prevent mitochondrial $\mathrm{O}_{2}{ }^{--}$generation by increasing proton flow into the matrix (Pappolla et al. 1999, Jiménez-Aranda et al. 2013).

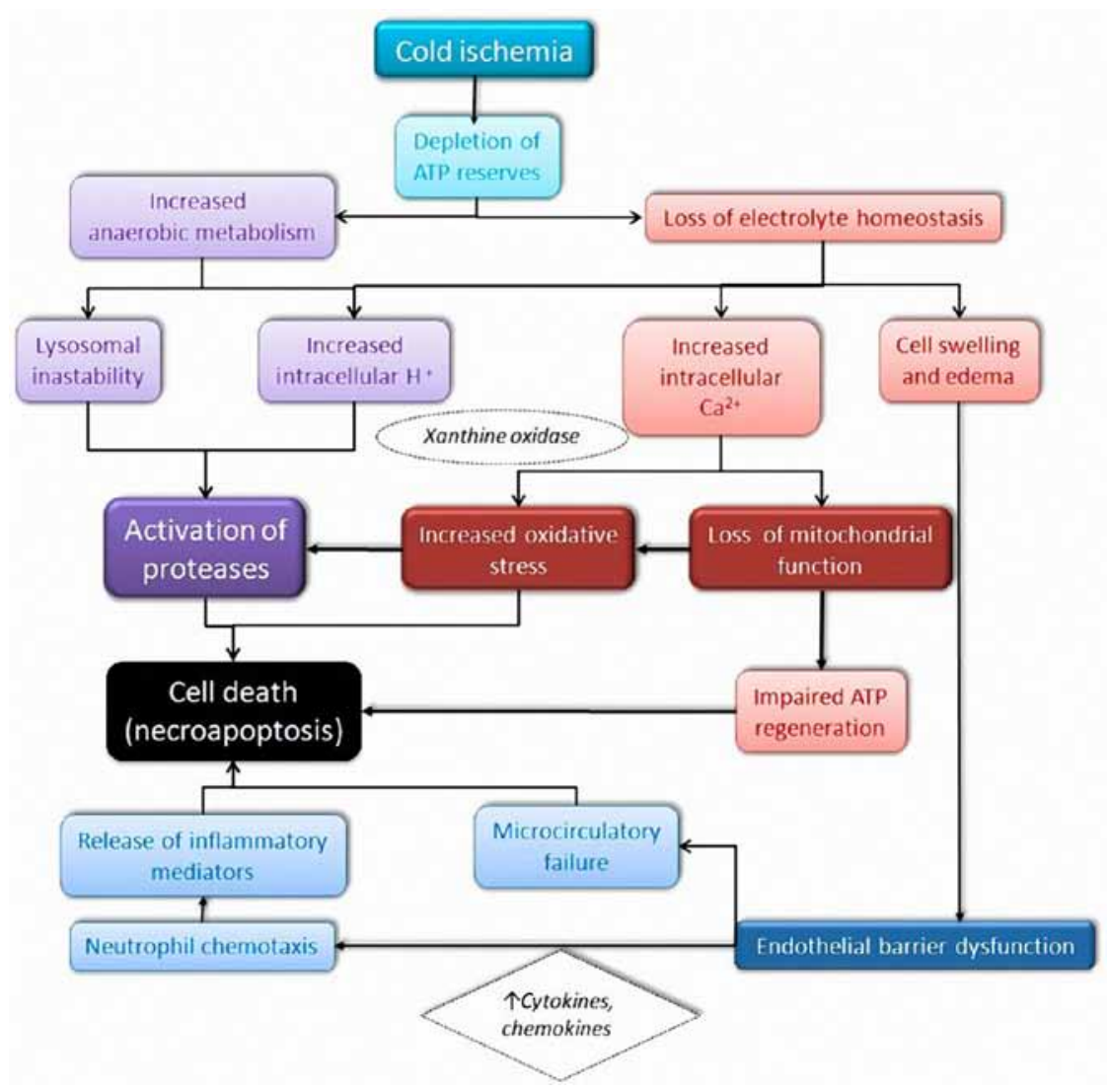

\section{Figure 1}

Liver IRI physiopathology. Cold ischemia induces cellular ATP depletion, which results in the loss of electrolyte homeostasis and increases anaerobic metabolism promoting intracellular $\mathrm{Ca}^{2+}$ and $\mathrm{H}^{+}$ accumulation and lysosomal instability. These events inhibit mitochondrial oxidative phosphorylation, thereby reducing ATP synthesis and activating proteases. Perturbations of electrolyte homeostasis generate cellular swelling and edema, which result in narrowing of the sinusoidal lumen and microcirculatory dysfunction via endothelial barrier dysfunction. These alterations contribute to organ neutrophil accumulation through the induction of neutrophil chemoattractants and adhesion molecules. Neutrophil extravasation generates parenchymal injury due to the production of ROS. Finally, cell death culminates in necrosis or apoptosis depending on the decline of cellular ATP (major degradation and no regeneration causes necrosis). A full colour version of this figure is available at http://dx.doi.org/10.1530/ JOE-16-0117.
(C) 2016 Society for Endocrinology Printed in Great Britain 
Melatonin also regulates the activity of a marker of mitochondrial membrane integrity that is reduced during IRI: mitochondrial glutamate dehydrogenase (GDH). Moreover, melatonin stabilizes microsomal membranes, enabling them, in a concentration-dependent manner, to resist the rigidity induced by free radical attack (García et al. 2014). Additionally, melatonin suppresses the cytochrome $c$ released into the cytoplasm due to mitochondrial swelling (Kim \& Lee 2008).

Finally, melatonin also preserves the functional and energetic status of cells during IRI by reducing concentrations of TNF- $\alpha$ (a pleiotropic cytokine generated by numerous cell types in response to various inflammatory and immunomodulatory stimuli) and inhibiting iNOS expression and NO. production. Melatonin augments the rise in eNOS mRNA levels, whereas it reduces the elevation of iNOS mRNA levels (Rodriguez-Reynoso et al. 2001, Kilic et al. 2005, Wang et al. 2005). This is important because eNOS-derived NO. is suggested to be an important protective factor against vascular endothelium pathophysiology because it is produced early and may abrogate the microcirculatory stress of engraftment and reperfusion. Conversely, iNOSderived NO- promotes ischemic injury by increasing free radical formation since it is generated several hours after stimulation and its production is not beneficial at this later time (Albrecht et al. 2003, Shah \& Kamath 2003). Some of the numerous processes by which melatonin functions as a direct free radical scavenger and indirect antioxidant are summarized in Fig. 2.

\section{Preservation solutions}

Preservation solutions play an important role in maintaining tissues for transplantation; these fluids have been subjected to numerous tests based on changes in ionic composition and in the inclusion of molecules designed to reduce intracellular and interstitial edema. During cold ischemia, sodium-potassium $\left(\mathrm{Na}^{+} / \mathrm{K}^{+}\right)$ATPase is inhibited elevating $\mathrm{Ca}^{2+}$ concentrations. This disturbance generates a local rise in intracellular osmolarity and edema and loss of membrane cell elasticity (Lang et al. 1995). To prevent this, a preservation solution including high- $\mathrm{K}^{+}$levels was examined, but not found to be useful because of the generated blood vessel constriction (Ramella-Virieux et al. 1997). The addition of 'impermeants' such as mannitol, raffinose, glucose, lactobionic acid, and gluconate or high $\mathrm{Na}^{+}$concentration was also not beneficial because these constituents diffused into the

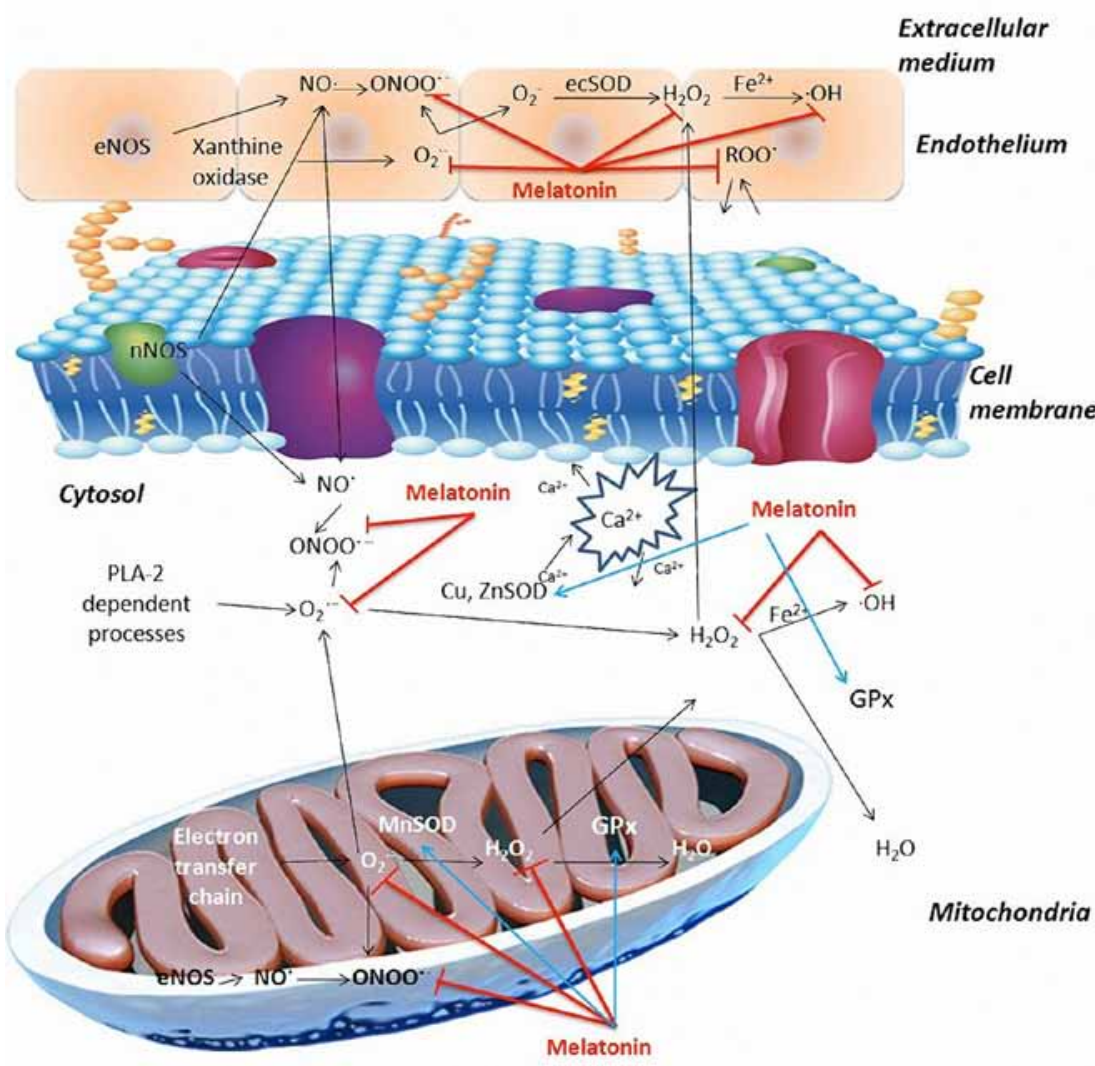

Figure 2

Melatonin's direct (red) an indirect effects (blue). In the endothelium, xanthine oxidase generates $\mathrm{O}_{2}$ - degrading xanthine to hypoxanthine; melatonin and its metabolites are scavengers of this and other ROS. Melatonin, in the extracellular medium and mitochondria, is also a scavenger of ONOO- generated as a result of the availability of NO- due to eNOS and nNOS activity. Furthermore, $\mathrm{O}_{2}$ - reactions with extracellular superoxide dismutase (ecSOD) give rise to $\mathrm{H}_{2} \mathrm{O}_{2}$, which suffers a reduction with $\mathrm{Fe}^{2+}$ generating $\cdot \mathrm{OH}$. Melatonin neutralizes these ROS. In the cytosol and mitochondria, similar processes occur with the action of MnSOD and Cu/ZnSOD. Glutathione peroxidase (GPX) reduces $\mathrm{H}_{2} \mathrm{O}_{2}$ to $\mathrm{H}_{2} \mathrm{O}$ and $\mathrm{O}_{2}$. Melatonin increases the activity of this enzyme and also the activity of SOD, which are important antioxidant enzymes. During IRI, a depletion of ATP occurs and an increase in intracellular $\mathrm{Ca}^{2+}$ develops, which increases oxidative stress and loss of mitochondrial function. eNOS, endothelial nitric oxide synthase; $\mathrm{H}_{2} \mathrm{O}_{2}$, hydrogen peroxide; iNOS, inducible nitric oxide synthase; NO, nitric oxide; PLA-2, phospholipase A2; ROO, alkyl peroxyl radical; $\mathrm{O}_{2}{ }^{-}$, superoxide radical; $\cdot \mathrm{OH}$, hydroxyl radical; ONOO-, peroxynitrite. A full colour version of this figure is available at http://dx.doi. org/10.1530/JOE-16-0117.

http://joe.endocrinology-journals.org DOI: 10.1530/JOE-16-0117
(C) 2016 Society for Endocrinology Printed in Great Britain 
interstitial medium and caused edema. Thereafter, it was observed that macromolecules called 'colloids' (albumin (Alb), hydroxyethyl starch, polyethylene glycol, and dextran) generate high oncotic pressure and the addition of these to solutions with low $\mathrm{Ca}^{2+}$, high $\mathrm{Na}^{+}$, and carefully adjusted $\mathrm{K}^{+}$and magnesium $\left(\mathrm{Mg}^{2+}\right)$ concentrations solved the problems observed earlier (Southard 1997).

University of Wisconsin solution (UW), Institute Georges Lopez solution (IGL-1), Celsior (CE) solution, EuroCollins solution, and histidine-tryptophan-ketoglutarate solution (HTK) are the most frequently used preservation solutions (Table 1). Euro-Collins solution was the first used, which does not contain oncotic agents but does contain glucose (impermeable to renal cells for short time but not in liver and pancreatic cells causing anaerobic metabolism of glucose and inducing intracellular acidosis) (Bejaoui et al. 2015).

It is presumed that preservation solutions with lower viscosity (like HTK) may improve graft survival (Puhl et al.

Table 1 Composition of cold storage solutions for organ preservation.

\begin{tabular}{|c|c|c|c|c|c|}
\hline & uW & CE & HTK & IGL-1 & $\begin{array}{l}\text { Euro- } \\
\text { Collins }\end{array}$ \\
\hline Osmolarity (mOsm/L) & 320 & 320 & 310 & 320 & 375 \\
\hline $\mathrm{pH}$ & 7.4 & 7.3 & 7.2 & 7.4 & 7.1 \\
\hline Viscosity (cp) & 5.70 & 1.15 & 1.8 & 1.28 & N/A \\
\hline $\mathrm{Na}^{+}(\mathrm{mmol} / \mathrm{L})$ & $25-30$ & 100 & 15 & 120 & 10 \\
\hline $\mathrm{K}+(\mathrm{mmol} / \mathrm{L})$ & $125-130$ & 15 & 10 & 30 & 115 \\
\hline $\mathrm{Mg}^{2+}(\mathrm{mmol} / \mathrm{L})$ & 5 & 13 & 4 & 5 & - \\
\hline $\mathrm{Ca}^{2}+(\mathrm{mmol} / \mathrm{L})$ & - & 0.25 & 0.015 & - & - \\
\hline $\mathrm{Cl}^{-}(\mathrm{mmol} / \mathrm{L})$ & - & 41.5 & 50 & 20 & 15 \\
\hline $\mathrm{PO}_{3}-(\mathrm{mmol} / \mathrm{L})$ & 25 & - & - & 25 & 47.5 \\
\hline $\mathrm{SO}_{4^{-}}(\mathrm{mmol} / \mathrm{L})$ & 5 & - & - & 5 & 30 \\
\hline $\mathrm{HCO}_{3}^{-}(\mathrm{mmol} / \mathrm{L})$ & - & - & - & - & 10 \\
\hline Glucose (mmol/L) & - & - & - & - & 195 \\
\hline Histidine (mmol/L) & - & 30 & 198 & - & - \\
\hline Tryptophan (mmol/L) & - & - & 2 & - & - \\
\hline Glutamate (mmol/L) & - & 20 & - & - & - \\
\hline $\begin{array}{l}\alpha \text {-Ketoglutarate } \\
(\mathrm{mmol} / \mathrm{L})\end{array}$ & - & - & 1 & - & - \\
\hline Lactobionate (mmol/L) & 100 & 80 & - & 100 & - \\
\hline Mannitol (g/L) & - & 60 & 30 & - & - \\
\hline $\mathrm{HES}(\mathrm{g} / \mathrm{L})$ & 50 & - & - & - & - \\
\hline PEG-35 (g/L) & - & - & - & 1 & - \\
\hline Raffinose (mmol/L) & 30 & - & - & 30 & - \\
\hline Adenosine (mmol/L) & 5 & - & - & 5 & - \\
\hline Allopurinol (mmol/L) & 1 & - & - & 1 & - \\
\hline Glutathione (mmol/L) & 3 & 3 & - & 3 & - \\
\hline
\end{tabular}

Additional ingredients in UW are penicillin $\mathrm{G}$, insulin, and dexamethasone. Viscosity data refer to a temperature of $4^{\circ} \mathrm{C}$. From Petrowsky and Clavien (2014) and Adam et al. (2015).CE, Celsior solution $\mathrm{cp}$, centipoises; HES, hydroxyethyl starch; HTK, histidine-tryptophanketoglutarate solution; IGL-1, Institute Georges Lopez solution; PEG-35, polyethylene glycol $35 \mathrm{kDa}$; UW, University of Wisconsin solution.
2006). It was also found that antioxidants and protective molecules such as polyethylene glycol $35 \mathrm{kDa}$ (PEG-35) in IGL1 solution and hydroxyethyl starch (HES) in UW solution improved the efficiency of the solutions and consequently graft survival. HTK solution is less effective because its composition is poor in these agents (Belzer \& Southard 1988).

Yang and He (2005) reviewed the data related to the use of preservation solutions in cardiac transplantation. The authors noted that UW was an effective tissue protector in heart transplantation (Swanson et al. 1988), but less effective in abdominal-tissue transplantation. This was because cardiac cells can only be preserved for 4-6h, while abdominal organs must be preserved for 24-48 h (Stringham et al. 1992). HTK solution is also observed to be effective by restricting the tissue acidosis induced by ischemia (Reichenspurner et al. 1993, Gu et al. 1996). In addition, some studies confirmed the efficacy of Celsior solution in reducing IRI (Menasché et al. 1994). Moreover, the authors observed that NO, hyperkalemia, and IRI made transplant outcomes worse, while $\mathrm{Mg}^{2+}$ and endothelium-derived relaxing factor attenuated these effects.

Pancreatic preservation fluids also have been studied. It is observed that UW produced results similar to those of HTK (Salehi et al. 2006) and better outcomes than Celsior solution (Hubert et al. 2007). For kidney transplantation, the UW solution provides good results in short- and longterm tissue preservation (Xiaodong \& Ashok 2010, Catena et al. 2013). IGL1 exhibits similar positive outcomes as UW (Codas et al. 2009) or even better (Badet et al. 2005).

Donderó et al. (2010) and Adam et al. (2015), in a liver transplantation review, summarized the data related to the utility of UW solution and IGL1 solution to resist graft rejection. A slight graft rejection increase with CE solution and a significant reduction with HTK solution was observed. Moreover, the authors observed that HTK caused major graft rejections and constitutes an independent risk factor compared with UW, which increased the probability of graft loss by $10 \%$. These results were also previously reported (Mangus et al. 2008, Stewart et al. 2004). Similar results were observed when CE and IGL1 were compared. Moreover, in partial grafts, IGL1 provided better survival than the other solutions because it increased the mediators that promote liver regeneration such as AMP-activated protein kinase (AMPK) (Bouma et al. 2010). Furthermore, UW and IGL1 solutions enriched with trophic factors, such as epidermal growth factor and insulin-like growth factor-1, are observed to enhance the resistance of steatotic livers

Published by Bioscientifica Ltd. 
to IRI, partly due to protein kinase B (PKB) and eNOS signaling activation, and reduced cytokine release (Zaouali et al. 2010a,b).

Attending to cardiac transplantation, preservation fluids also play a pivotal role in graft survival. A solution consisting of melatonin $(100 \mathrm{mmol} / \mathrm{L})$, adenosine $(400 \mu \mathrm{mol} / \mathrm{L})$, lidocaine $(1000 \mu \mathrm{mol} / \mathrm{L})$, and insulin $(0.01 \mathrm{IU} / \mathrm{mL})$ was compared with adenosine-lidocaine cardioplegia with low $\mathrm{Ca}^{2+} /$ high $\mathrm{Mg}^{2+}$ concentration levels, HTK solution, and Celsior solution (Rudd \& Dobson 2011). The authors observed a higher recovery of aortic flow and coronary flow by using the melatonin preservation solution compared with other treatments. Heart rate and systolic pressure were also better in this group. In addition, lactate levels were lower in these animals, and troponin values were not detected after $5 \mathrm{~min}$ of reperfusion, as observed in the adenosinelidocaine-treated rats.

Preservation solutions also play an important role in kidney transplantation. Melatonin added to UW solution decreases significantly MDA and lactate dehydrogenase (LDH) more than UW solutions without melatonin in transplanted kidneys (Aslaner et al. 2013).

In liver transplantation, adding melatonin at a concentration of $100 \mu \mathrm{M}$ in Krebs-Henseleit bicarbonate (KHB) solution and added to UW and Celsior solutions attenuates the histopathological effects produced during IRI of hepatocytes (Freitas et al. 2006). LDH and GSH levels of melatonin-treated rats were similar to control values. ATP levels were restored by melatonin after IRI; these values are usually reduced seven-fold. These results are in agreement with previous studies (Vairetti et al. 2005), but in this case a dose-dependent effect of melatonin on bile production and biliary bilirubin secretion also was observed. ATP levels were likewise increased and GGT levels reduced. GSH and LDH did not exhibit any modifications. These benefits were better when melatonin was added to the UW solution than to the Celsior solution.

The ubiquitin proteasome system (UPS) is an energydependent system that degrades misfolded proteins and regulates various cellular processes (Padrissa-Altés et al. 2012). In liver, it has been recently demonstrated that the addition of the reversible UPS inhibitors bortezomib (BRZ) and carbobenzoxy-Leu-Leu-leucinal (MG132) to UW solution improved steatotic and nonsteatotic liver preservation, and that the protective effect of BRZ was superior to that of MG132 (Zaouali et al. 2013a). IGL1 solution supplemented with BRZ also showed protective effects which were partially mediated through the activation of AMPK and Akt/mTOR signaling (Bejaoui et al. 2014). Melatonin has similar actions to BRZ, which could contribute to the ability of melatonin to protect transplanted tissues (Vriend \& Reiter 2014a,b).

\section{Organ transplantation}

\section{Cardiac transplantation}

Cardiac transplantation is a useful treatment for patients with end-stage heart failure or severe coronary arterial disease (Gill 2008). The outcome of these procedures have improved using cyclosporine (CsA) as an immunosuppressive therapy (Aumente et al. 2005), but this drug has several limitations due to its side effects (Baan et al. 1994). Melatonin has been studied as an agent to protect against graft rejection.

In a rat model using Thomas solution with melatonin ( $0.1 \mathrm{mmol} / \mathrm{L})$ (Gao etal. 2003), cardiac functional recovery, coronary vasodilatory response to acetylcholine chloride, and myocardial high energy phosphate findings, were much better than those of control animals after $12 \mathrm{~h}$ of hypothermic ischemia. Furthermore, creatine kinase (CK) levels were lowered in treated group after $15 \mathrm{~min}$ of reperfusion. In addition, degeneration, swelling, and loss of normal dense granules in mitochondria were observed in non-melatonin-treated animals, but not in treated rats. These results are in agreement with another study where melatonin was given orally suspended in $1.5 \mathrm{~mL}$ saline solution (one group received $20 \mathrm{mg} / \mathrm{kg}$ and another group $200 \mathrm{mg} / \mathrm{kg}$ melatonin) (Jung et al. 2004). The authors observed a prolonged allograft survival in the melatonin-injected animals ( $7.3 \pm 1$ and $12.3 \pm 1$ days, respectively) versus control rats ( $6.3 \pm 1$ days) due to a decreased proliferative capacity of recipient lymphocytes and due to a reduction in the synthesis of allospecific antibodies.

Melatonin also produced beneficial effects in cardiac transplantation through a synergetic action with CsA in a rat model (Liu et al. 2014). The authors administered $200 \mathrm{mg} / \mathrm{kg} / \mathrm{day}$ of melatonin to one group, $20 \mathrm{mg} / \mathrm{kg} / \mathrm{day}$ of CsA to the second group, and $50 \mathrm{mg} / \mathrm{kg} / \mathrm{day}$ of melatonin with $5 \mathrm{mg} / \mathrm{kg} /$ day of CsA to the third group. CsA was more effective than melatonin alone on graft survival, but combining these drugs gave the best result (31.6 \pm 2.4 days). This finding may have been a result of a reduction in the expression of $P 65, B c l 2$, and $I l 1 \beta$, which are key genes in inflammation and apoptosis. Histopathological data showed a similar release of inflammatory cytokines, including IL2 and TNF- $\alpha$, and

Published by Bioscientifica Ltd 
cell apoptosis in melatonin and CsA group. However, the addition of these drugs produced an important decrease in heart congestion and cell survival. The results suggest that melatonin may be effective in prolonging cardiac allograft survival and reducing the dose of CsA, thereby reducing the side effects of the drug.

\section{Bone transplantation}

Melatonin is observed to be a promoter of bone formation invivo, enhancing both the proliferation and differentiation of osteogenic cells (Takechi et al. 2008). Moreover, the indoleamine may increase gene expression of bone sialoprotein as well as other proteins and bone markers reducing the osteoblast differentiation period (Roth et al. 1999). Also, melatonin interferes with osteoclast activity, which is enhanced due to free radical actions. Melatonin limits the suppression of bone resorption due to its ability as a free radical scavenger (Koyama et al. 2002) and by downregulating nuclear factor B-mediated osteoclast activation (Ostrowska et al. 2010).

Pinealectomy generates spinal deformities due to the reduction in melatonin (Turgut et al. 2003). The authors also observed a reduction in the number of chickens with scoliosis with an enhanced values of Cobb angle and rib-vertebra value in pineal-transplanted birds versus pinealectomized chicks. The differences were not statistically significant between both groups, whereas significantly larger than those found in control group. Serum melatonin levels were depressed after pinealectomy, but pineal-transplanted animals were observed to have increased levels of melatonin, but the differences were also not statistically significant. Due to that, the authors conclude that the role of melatonin in the development of spinal deformity in chickens after pinealectomy remains controversial.

In a tibia rabbit model, melatonin (1.2 $\mathrm{mg}$ lyophilized powdered melatonin applied topically) added to a porcine bone graft was shown to improve new bone formation and cortical bone length compared with control animals or porcine bone alone at 15, 30, 45, and 60 days post-transplantation (Calvo-Guirado et al. 2015). These effects were the result of an increase in osteoblast proliferation in the peri-implant zone with an accelerated cell differentiation of the osteoid matrix. Melatonin's beneficial effects were observed radiographically and related to the $\mathrm{Ca}^{2+}$ levels, which were higher in melatonin-treated animals than in other groups. These results were statistically significant at 15 and 30 days post-transplantation.

\section{Otolaryngology transplantation}

Subtotal and total ear reattachment is a difficult surgery with a poor graft survival (Grabb \& Dingman 1972). It has been shown that methylprednisolone sodium, dimethylsulfoxide, chlorpromazine, and indomethacin significantly improve survival of reimplanted auricular cartilage grafts in rabbits (Aden \& Biel 1992, Henrich et al. 1995). Melatonin's benefits during auricular transplantation $(500 \mathrm{mg} / \mathrm{kg}$ i.p.) were compared in a rat model versus dimethylthiourea (DMTU) and hyperbaric oxygen (HBO) (Lim et al. 1999). Template weights showed a significant improvement in graft survival with all treatments at days 7, 14, and 21. However, during photographic analysis, significant differences in graft survival were only found at day 7. Moreover, DMTU was the most effective treatment and $\mathrm{HBO}$ the worst.

\section{Ovarian grafts}

CsA has been used for several years to inhibit the recipient immune reaction during ovarian transplantation, but there is an important toxicity following its use (Ergüder et al. 2005). Thus, antioxidants including DMSO, 1,2-propanediol (PROH) (Abir et al. 2009), and vitamin E (Nugent et al. 1998) were used with beneficial effects in ovarian graft survival. Melatonin is known to be involved in ovarian physiology including follicular development, ovulation, oocyte maturation, and luteal function (Adriaens et al. 2006; Reiter et al. 2009b, Tamura et al. 2009). Furthermore, endometriosis is observed to be favored in pinealectomized rats with decreased levels of SOD and CAT activities and elevated MDA concentrations (Koc et al. 2010). Because of this and the antioxidant capacities of melatonin, its metabolites (Alvarez-Diduk et al. 2016) have been studied to prevent ovarian graft rejection.

Melatonin at doses of 20,50,100, and $200 \mathrm{mg} / \mathrm{kg}$ /day i.v. were used in a rat model to improve ovarian graft survival (Hemadi et al. 2012). With doses of 20 or $50 \mathrm{mg} / \mathrm{kg}$, melatonin increased IL2 and interferon (IFN)- $\gamma$ levels. However, at higher doses, the authors observed significant reductions of these cytokines. IL10 levels were also decreased using 100 and $200 \mathrm{mg} / \mathrm{kg}$ of melatonin. By comparison, IL4 levels were not changed when using the drug. Relative to allospecific serum antibodies (IgM, IgG, IgG1a, and IgG2a), the authors only founded significant benefits using 100 and $200 \mathrm{mg} / \mathrm{kg}$ of melatonin with a drop in IgM and IgG2a levels compared with control values. However, at the morphological level, these higher doses

Published by Bioscientifica Ltd. 
did not appear to be beneficial. Apoptosis of primordial follicles also followed melatonin administration. There were no healthy antral follicles in the vitrified thawed ovaries treated with melatonin 6 days after transplant, but they did reappear at the seventh day after transplantation in both nontreated and most melatonin-treated ovaries.

Melatonin ( $20 \mathrm{mg} / \mathrm{kg}$ i.p.) also was compared with oxytetracycline $(10 \mathrm{mg} / \mathrm{kg}$ i.p.) in an autologous intraperitoneal ovary transplantation system in rats (Sapmaz et al. 2003). Melatonin was statistically significantly more effective in reducing ovarian necrosis and tissue MDA levels than was oxytetracycline. The indoleamine $(240 \mathrm{mg} / \mathrm{L}$ orally) was also compared with hyaluronan (HA), vascular endothelial growth factor A (VEGF-A) $(200 \mathrm{ng} / \mathrm{mL})$, and vitamin $\mathrm{E}(400 \mathrm{IU} / \mathrm{mL})$ in a human ovarian material study after its transplantation into immunodeficient mice (Friedman et al. 2012). The authors observed a reduced apoptosis in all treated animals, but these results were statistically significant in melatonin + HA-rich biological glue + VEGF-A + vitamin E animals. There were no significant differences in VEGF-A expression among the tissues. Atretic follicles were significantly higher in the untreated animals than in the treated groups.

\section{Testicular grafts}

Spermatogenesis is disrupted during radiotherapy or chemotherapeutic treatment and the freezing of semen before treatment is the principal means of solving this problem (Lass et al. 2001, Agarwal \& Allamaneni 2005). This treatment is obviously not useful for children, and about $2 \%$ of all malignant cancers occur during childhood and infancy (Brougham \& Wallace 2005). Leydig cells and Sertoli cells are known to have receptors for melatonin and it has been suggested that melatonin may play a role in the spermatogenesis process (Frungieri et al. 2005).

Testicular grafts have been studied to promote spermatogenesis and melatonin is suggested to reduce transplant rejection rates. Hemadi et al. (2014), using a vitrified testicular graft model, observed that melatonin $(20 \mathrm{mg} / \mathrm{kg}$ orally per day) reduces atrophic cords and improve preservation results of the morphological histology of the tissues than did nontreatment. These beneficial effects included a higher percentage of intact seminiferous tubules with ongoing spermatogenesis, reduced levels of activated myoid cells, decreased rate of lysosomes, phagolysosomes and lipid droplets in the Sertoli cells, more preserved Leydig cells, and a rise in the number of mitochondria with well-developed cristae. The differences were statistically significant.

Spermatogonial cell transplantation into the testes of infertile animals was observed to lead to the reoccurrence of spermatogenesis (Orwig \& Schlatt 2005, Mikkola et al. 2006, Kim et al. 2008). Melatonin treatment (20 mg/kg i.p. daily for 10 weeks after transplantation) was studied by Gholami et al. (2014) in a mice model. The results showed that large number of sperm was found in the lumen of seminiferous tubes with complete spermatogenesis in melatonin-treated animals. Furthermore, the morphological structure and the number of Leydig cells were also preserved. These results are in agreement with previous studies, where the administration of melatonin to azoospermic mice led to a complete regeneration of germ cells with the appearance of elongated and round spermatids (Mohammadghasemi et al. 2010).

\section{Lung transplantation}

Lung transplantation is an effective therapeutic option in the treatment of patients with end-stage pulmonary diseases. However, early acute graft dysfunction is a serious obstacle in obtaining a successful outcome due to significant postoperative morbidity and mortality (Hosepund et al. 1999). It is observed that IRI is a common complication after lung transplantation; this is characterized by nonspecific alveolar damage and pulmonary edema (De Perrot et al. 2003).

Inci et al. (2002) studied the IRI effects after lung transplantation and the ability of melatonin to prevent the damage in a rat model. Significantly higher oxygen blood levels $2 \mathrm{~h}$ after graft reperfusion was observed in melatonin-treated versus nontreated animals. Peak airway pressures and bronchoalveolar lavage nitrite values were also statistically significantly lower in treated animals. MDA levels generated by LPO and MPO activity were also significantly lower as a result of melatonin treatment.

Melatonin's beneficial effects against IRI after lung transplantation were also compared with other antioxidants including estradiol $(25 \mathrm{mg} / \mathrm{kg}$ i.p.) and desferrioxamine $(20 \mathrm{mg} / \mathrm{kg}$ i.p.) in a rat model (Santana-Rodríguez et al. 2011). The authors observed that melatonin $(10 \mathrm{mg} / \mathrm{kg}$ i.p.) had similar effects to desferrioxamine in preventing IRI based on radiological evidence. However, estradiol treatment induced several complications, including moderate-to-severe edema. There were no significant differences between any treatment groups in terms of their efficacy against acute graft rejection.

Published by Bioscientifica Ltd. 
CD26/dipeptidylpeptidase IV (CD26/DPP IV) is observed to modulate the biological effects of several chemokines, hematopoietic growth factors, neuropeptides, and hormones (Lambeir et al. 2003). As a result, it was predicted that this treatment may reduce IRI in lung transplantation (Jung et al. 2006, Zhai et al. 2007). The beneficial effects of this treatment against graft rejection were compared with melatonin (10 mg/kg i.p.) in a rat model (Zhai et al. 2009). The authors observed a significantly poorer outcome in terms of graft survival after 7 days in melatonin-treated animals compared with those given CD26/DPP i.v. This study also reported an improvement of lung function and histological structure, decreased MDA levels, reduced MPO activity, and reduced vasoactive intestinal peptide levels, a neuropeptide involved in pulmonary parenchyma physiology with the latter treatment. These measures were statistically significant and were not investigated in the melatonin-treated animals.

\section{Pancreas transplantation}

Melatonin ( $10 \mathrm{mg} / \mathrm{kg} / \mathrm{day} / 6$ weeks) was shown to ameliorate type 2 diabetes mellitus associated with obesity due an increase of $\mathrm{Ca}^{2+}$ in muscle, liver, different adipose tissues, and pancreas in rats (Agil et al. 2015), and it reduced age-related insulin resistance in senescence-accelerated mice (Tresguerres et al. 2013). Moreover, blood levels of ghrelin, leptin, and melatonin are elevated in the initial phase of pancreatic inflammation, suggesting that these hormones could be a part of the innate resistance system against this condition. The exogenous administration of these substances produces a significant attenuation of severity of pancreatitis and protects pancreatic tissue from inflammatory damage. These beneficial effects are a result of inhibition of NF-kB, modulation of cytokine production, stimulation of heat shock protein (HSP), and the activation of the antioxidant system (Jaworek \& Konturek 2014). As a result, melatonin also modulates pancreatic carcinogenesis through its direct and indirect actions and by increasing the efficacy of oncostatic drugs (Jaworek \& Leja-Szpak 2014).

Once diabetes mellitus evolves, pancreas transplantation is an effective therapy, but technical failures and early graft failures due to loss of primary function are responsible for graft loss in 6-10\% and $3-5 \%$ of the cases, respectively (Wullstein et al. 2004, Gruessner \& Sutherland 2005). IRI is associated with alterations in mitochondrial function, which leads to the formation of oxygen-derived free radicals and LPO of the phospholipids in the cell membrane generating MDA and 4-HDA (García-Gil et al. 2006, 2012); melatonin, in a rat model, reduces these degenerative changes (Muñoz-Casares et al. 2006). In addition, acute graft rejection is linked to a loss of organ function due to an increase in glucose concentrations and a reduction in membrane fluidity in pigs (García Gil et al. 2012).

There are few studies related of the ability of melatonin to prevent pancreas graft rejection. It has been observed that in nonobese diabetic (NOD) mice, melatonin $(200 \mathrm{mg} / \mathrm{kg}$ s.c.) prolongs pancreatic islet graft survival (Lin et al. 2009). The authors, however, did not observe differences of glucose or insulin levels in these animals. Melatonin decreased T helper 1 (Th1) cell levels, which play a pathogenic role during the initiation of the disease process. Consequently, melatonin reduced in a significant manner the proliferative capacity of recipient splenocytes due to a reduction in the expression of concanavalin A and CD3, which stimulates Th1. Furthermore, melatonin treatment significantly increased the population of IL10-producing CD4 T cells supporting their protective effects. The indoleamine also decreased the expression of cytokines (IFN- $\gamma$, TNF- $\alpha$, IL4, IL1 $\beta$, and TGF- $\beta$ ), but it did not influence systemic lymphocyte development. TNF- $\alpha$ results were only statistically significant.

The antioxidative effects of melatonin and ascorbic acid (AA) were compared in a pig transplantation model (García-Gil et al. 2011); both were given at $10 \mathrm{mg} / \mathrm{kg}$ i.v. AA did not increase graft survival, while melatonin animals showed a significant rise in graft survival. This result was reflected in pancreatic function with better maintenance of normoglycemic status in the melatonintreated pigs. Markers of LPO (MDA+4-HDA) were also decreased by both antioxidants, but the results were better in melatonin-treated pigs. Acute-phase protein/ inter- $\alpha$-trypsin inhibitor heavy chain 4 (pMAP/ITIH4), an acute protein observed during graft rejection, was only inhibited in pigs given melatonin. The authors did not report significant differences in amylase levels.

\section{Kidney transplantation}

Chronic kidney diseases lead to high oxidative stress markers and hemodialysis is not sufficient to adequately control these pathophysiologies (Pawlak et al. 2007). Like other organs, these conditions may benefit from organ transplantation and several studies observed changes in these markers after kidney transplantation (Simmons et al. 2005). The problem is that the inflammatory response generated by the graft implant may generate

Published by Bioscientifica Ltd. 
oxidative stress and organ rejection (Vural et al. 2005, Barakat et al. 2010). Moreover, it is observed that diabetic patients have a further increase of oxidative markers due to their illness; this is associated with a poorer kidney allograft function (Morales-Indiano et al. 2009).

Several studies have tested antioxidants such as $\mathrm{N}$-acetyl-cysteine (NAC) (Erdogan et al. 2006), vitamin $\mathrm{C}$ and $\mathrm{E}$ (Loong et al. 2004), and melatonin (Quiroz et al. 2008) in terms of their ability to reduce IRI. Melatonin $(500 \mu \mathrm{g} / \mathrm{kg})$ also provides protection against CsA-induced nephrotoxicity by decreasing blood urea, serum creatinine, and plasma MDA levels, and increasing creatinine and lithium clearance (Kumar et al. 1999). These disturbances are a result of oxidative stress injury. Similar protective antioxidant effects are observed against tacrolimus nephrotoxicity in a rat model; the protection by melatonin $(4 \mathrm{mg} / \mathrm{kg}$ i.p.) is the result of its ability to modulate the increase of TNF- $\alpha$, IL6, NO, and MDA levels (Ara et al. 2011). All results were statistically significant except those related to MDA levels.

Donor preconditioning with melatonin $(50 \mathrm{mg} / \mathrm{kg}$ orally) was observed to prolong graft survival in a rat model of kidney transplantation (Li et al. 2009). Blood urea nitrogen (BUN), creatinine, transaminases, and LDH levels were increased in control animals after transplantation; melatonin reduced these levels significantly. The authors also observed that the indoleamine induced an elevation of tissue SOD while reducing lipid hydroperoxide levels. Melatonin also modulated the immune response by downregulating the expression of NF-кB p65, thereby modifying the activity of iNOS and caspase-3. In addition, a significant reduction in the histological damage of renal tubules was apparent.

Another problem observed after kidney transplantation is the disturbance in circadian rhythms and sleep-wake cycles including poor sleep quality, poor daytime functioning, and daytime sleepiness. These patients experience insomnia, restless legs syndrome (a neurological disorder), and obstructive sleep apnea (Burkhalter et al. 2015). It is suggested to be a result of an innate immune response (Kapsimalis et al. 2008, Besedovsky et al. 2012) or due to the inflammatory effects generated after transplantation (Castanon-Cervantes et al. 2010). A human multicenter study (Burkhalter et al. 2015) observed that the daytime bright light therapy improved sleep quality and the disorders derived from it. Decreased levels of melatonin were also observed in all patients, and the authors suggested that the intake of $\beta$-blockers and acetylsalicylic acid likely interfered with melatonin secretion, as shown in previous studies
(Brismar et al. 1988). However, melatonin levels in control subjects were similar to those in the intervention group, and behaviorally the patients showed significant statistical improvement as a result of melatonin. These results are in agreement with other studies (Russcher et al. 2015). In the latter case, the authors also did not observe beneficial effects on sleep quality due to melatonin-mediated improvement of renal function after transplantation; conversely, in an unpublished claim, kidney transplantation was associated with a rise of melatonin levels and an improvement in sleep quality due to the recovery of organ function (M Russcher, B C P Koch, C A J M Gaillard, J E Nagtegaal \& $\mathrm{P}$ M Ter Wee, unpublished observations).

It is well known that a worst renal function is associated with sleep disorders (Ezzat \& Mohab 2015). This may be a result of an imbalance between defensive agents (melatonin is decreased) and an increasing cell death rate due to the rise in oxidative markers such as TNF- $\alpha$ (Pinto et al. 2016). However, with improved renal function, low melatonin-related sleep disorders are observed to be reduced. More studies are clearly needed to define the circadian rhythm disturbances that accompany kidney transplantation.

\section{Liver transplantation}

Liver transplantation is the last-resort treatment for the end stage of both acute and chronic hepatic diseases. IRI, inherent in every liver transplantation process, is responsible of $81 \%$ of retransplantations during the first week after surgery due to poor function or primary nonfunction of the liver allograft (Belzer \& Southard 1988, Shaw 1995). Graft failures are caused by prolonged cold storage, especially when steatosis is present. Also, donor fatty livers are associated with increased levels of recipient morbidity, mortality, and increased sensitivity to IRI (Chavin et al. 2004). This occurs because liver steatosis exhibits microvascular alterations, mitochondrial dysfunction, and a lower number of sinusoids, which increase IRI (Hui et al. 2004). Steatotic liver grafts are also associated with a primary nonfunction rate of $60 \%$ compared with less than $5 \%$ for nonsteatotic grafts (Selzner \& Clavien 2001, Farrel et al. 2008).

During liver failure, ammonia levels may cause the arrhythmic release of melatonin from the pineal gland; this arrhythmicity is corrected after successful liver transplantation (Córdoba et al. 2009). However, whether these associations are real is questioned because it also suggested that hyperbilirubinemia (a pathological status

Published by Bioscientifica Ltd 
in liver failure patients) may interfere with the plasma melatonin assay (Middleton 2006).

AMPK activation during IRI leads to the stimulation of fatty acid oxidation and inhibition of lipogenesis, glucose production, and protein synthesis (Viollet et al. 2006). The activation of this enzyme produces the accumulation of $\alpha$-subunit of hypoxia-inducible factor- 1 (HIF $1 \alpha$, a transcription factor that functions as a master regulator of adaptive responses to reduced $\mathrm{O}_{2}$ availability) (Fisslthaler \& Fleming 2009) and induces NO. generation, which impairs the normoxic degradation of HIF1 $\alpha$ (Zaouali et al. $2010 c$ ). In fatty livers, the combined effect of melatonin and trimetazidine ( $\mathrm{TMZ}$ at $10^{-3} \mu \mathrm{M}+$ melatonin $100 \mu \mathrm{M}$ ) as additives to IGL1 was observed to induce AMPK activation and enhance eNOS induction; as a consequence, HIF1 $\alpha$ was stabilized (Zaouali et al. 2013b). The combination of drugs caused the activation of protective genes including $H s p 70$, Bcl2, erythropoietin, Vegf, and heme oxygenase-1 (Ho1) (Zaouali et al. 2013a). The benefits of the TMZ+ melatonin cocktail added to IGL1 preservation solution in reducing endoplasmic reticulum stress and increasing autophagy in fatty liver grafts through the modulation of AMPK activity were also observed by other workers (Matsui et al. 2008, Wang et al. 2011).

The beneficial actions of melatonin were investigated by examining a pharmacological pretreatment cocktail, which included pentoxifylline $(50 \mathrm{mg} / \mathrm{kg}$ intra-arterial), glycine $(100 \mathrm{mg} / \mathrm{kg}$ intra-arterial), deferoxamine $(30 \mathrm{mg} / \mathrm{kg}$ intraarterial), NAC (150mg/kg i.p.), erythropoietin (1000IU i.p.), simvastatin (5 mg/kg intragastric), and melatonin $(10 \mathrm{mg} / \mathrm{kg}$ i.p.) (von Heesen et al. 2011). The authors observed that the addition of melatonin induced a decrease of TNF- $\alpha$ and intercellular adhesion molecule 1 (ICAM1) levels (ICAM1 is induced by TNF- $\alpha$ and IL-1), with a significant attenuation of hepatic leukocyte infiltration, vacuolization, and cell death. This group also observed that with the multidrug treatment, MDA levels also lowered liver enzymes and excretory liver function levels were recovered to nearly control levels (von Heesen et al. 2012). These authors also used another multidrug treatment based on curcumin (50 $\mathrm{mg} / \mathrm{kg}$ intragastric), simvastatin ( $5 \mathrm{mg} / \mathrm{kg}$ intrasgastric), NAC (150 mg/kg i.p.), erythropoietin (3000IU/kg i.p.), pentoxyphylline ( $50 \mathrm{mg} / \mathrm{kg}$ i.p.), melatonin ( $10 \mathrm{mg} / \mathrm{kg}$ i.p.), glycine (100 mg/kg intra-arterial), and methylprednisolone $5 \mathrm{mg} / \mathrm{kg}$ intra-arterial (Moussavian et al. 2011). The significant increases of $\mathrm{K}^{+}$(a cell membrane integrity marker), and ALT, AST, and LDH (parenchymal cell death indicators) were normalized by pretreatment with this cocktail. Furthermore, bile flow was restored and TNF- $\alpha$, IL6, and MDA levels were reduced. These improvements were in agreement with the histopathological findings, where a reduced vacuolization and caspase- 3 expression was seen when melatonin was added to the cocktail.

Isolated primary human hepatocytes represent an alternative treatment to orthotopic liver transplantation (Smets et al. 2008, Fitzpatrick et al. 2009), and also a pathway to developing extracorporeal bioartificial livers (Allen et al. 2001). The problem is that during the isolation process, hepatocytes suffer IRI (Francés et al. 2007). A recent study (Solanas et al. 2015) used melatonin or DMSO to prevent this injury (perfusion with $5 \mathrm{mM}$ melatonin compared with perfusion with 1\% DMSO). These antioxidants produced similar cell viability and cell attachment results. Cellular dehydrogenase activity, urea and Alb levels, 7-ethoxycoumarin O-deethylase (a market of cytochrome P450 activity) activity were also increased by melatonin and were not statistical significant different from DMSO. The indoleamine was, however, better at decreasing LPO in hepatocytes than was DMSO.

Human dental pulp stem cells (hDPSCs) are observed to differentiate into hepatocyte-like cells (Ishkitiev et al. 2012). Because of this, a recent study tested the benefits of this treatment and melatonin $(5 \mathrm{mg} / \mathrm{kg}$ i.p. twice a week) against liver cirrhosis (Cho et al. 2015). The authors observed a dose- and time-dependent relationship between melatonin and hepatic markers such as Alb, cytokeratin-18 (Ck18), CCAAT box enhancer-binding protein $\alpha(C / E b p \alpha)$, and hepatic nuclear factor- $1 \alpha(H n f 1 \alpha)$. In addition, improvement of the immune response and a decrease of ALT, AST, and ammonia serum levels were also observed as a result of the addition of melatonin.

\section{Conclusions}

Melatonin's role preventing graft rejection and improving organ transplantation results have been studied principally in animal models. Nowadays, there are not many studies in human models. Therefore, it is impossible to confirm the indoleamine benefits in our species, but the results observed in animals are encouraging. In addition, we observed that melatonin dose used in organ transplantation is between 1000- and 3000-fold difference compared with melatonin dose for sleep and jet lag. Because of this difference of dosage, melatonin's pathway differs. In organ transplantation, the indoleamine effects are observed to be produced due to its free radical scavenger properties, while its benefits in sleep promotion and jet lag prevention are mediated

Published by Bioscientifica Ltd 
by melatonin action via indoleamine receptors (Laudon \& Frydman-Marom 2014).

In conclusion, organ transplantation may be a useful therapeutic tool for the treatment of patients with endstage organ failure. Outcomes of these procedures have been improved recently by using new solutions to prevent graft rejection allowing for a great variety of organs to be transplanted. IRI occurs during organ transplantation and melatonin may be protective because of the findings summarized herein. Furthermore, melatonin is effective in not only reducing graft rejection, but it also improves organ function during the post-transplant period. Melatonin's benefits are a result of its direct and indirect effects in cells. Moreover, melatonin is observed to increase the effectiveness of organ fluid preservation, which also plays a pivotal role in organ transplantation by reducing graft rejection. The observed results open a new advance for improvement of this important surgical technique. Additional studies would aid in defining additional mechanism to explain the beneficial actions of this endogenously produced and exogenously administered melatonin.

\section{Declaration of interest}

The authors declare that there is no conflict of interest that could be perceived as prejudicing the impartiality of this review.

\section{Funding}

This work did not receive any specific grant from any funding agency in the public, commercial, or not-for-profit sector.

\section{Author contribution statement}

All authors agree with the work done and have collaborated actively in its development.

\section{Acknowledgements}

The authors would like to thank the Department of Cellular and Structural Biology of University of Texas Health Science Center at San Antonio for hosting E E Z during the preparation of this review.

\section{References}

Abir R, Biron-Shental T, Orvieto R, Garor R, Krissi H \& Fisch B 2009 Transplantation of frozen-thawed late-gestational-age human fetal ovaries into immunodeficient mice. Fertility and Sterility 92 770-777. (doi:10.1016/j.fertnstert.2008.06.032)

Acuña-Castroviejo D, Escames G, Venegas C, Díaz-Casado ME, Lima-Cabello E, López LC, Rosales-Corral S, Tan DX \& Reiter RJ 2014
Extrapineal melatonin: sources, regulation, and potential functions. Cellular and Molecular Life Sciences 71 2997-3025. (doi:10.1007/ s00018-014-1579-2)

Adam R, Delvart V, Karam V, Ducerf C, Navarro F, Letoublon C, Belghiti J, Pezet D, Castaing D, Le Treut YP, et al. 2015 ELTR contributing centres, the European Liver, Intestine Transplant Association (ELITA). Compared efficacy of preservation solutions in liver transplantation: a long-term graft outcome study from the European Liver Transplant Registry. American Journal of Transplantation 15 395-406. (doi:10.1111/ajt.13060)

Aden KK \& Biel MA 1992 The evaluation of pharmacologic agents on composite graft survival. Archives of Otolaryngology - Head and Neck Surgery 118 175-178. (doi:10.1001/archotol.1992.01880020073018)

Adriaens I, Jacquet P, Cortvrindt R, Janssen K \& Smitz J 2006 Melatonin has dose-dependent effects on folliculogenesis, oocyte maturation capacity and steroidogenesis. Toxicology 228 333-343. (doi:10.1016/j. tox.2006.09.018)

Agarwal A \& Allamaneni SS 2005 Disruption of spermatogenesis by the cancer disease process. Journal of the National Cancer Institution Monographs 34 9-12. (doi:10.1093/incimonographs/lgi005)

Agil A, Elmahallawy EK, Rodríguez-Ferrer JM, Adem A, Bastaki SM, Al-Abbadi I, Fino Solano YA \& Navarro-Alarcón M 2015 Melatonin increases intracellular calcium in the liver, muscle, white adipose tissues and pancreas of diabetic obese rats. Food \& Function 6 2671-2678. (doi:10.1039/c5fo00590f)

Albrecht EW, Stegeman CA, Heeringa P, Henning RH \& van Goor H 2003 Protective role of endothelial nitric oxide synthase. Journal of Pathology 199 8-17. (doi:10.1002/path.1250)

Allen JW, Hassanein T \& Bhatia SN 2001 Advances in bioartificial liver devices. Hepatology 34 447-455. (doi:10.1053/jhep.2001.26753)

Alvarez-Diduk R, Galano A, Tan DX \& Reiter RJ 2016 The key role of the sequential proton loss electron transfer mechanism on the free radical scavenging activity of some melatonin-related compounds. Theoretical Chemistry Accounts 135 1-5. (doi:10.1007/s00214-015-1755-y)

Ara C, Dirican A, Unal B, Bay Karabulut A \& Piskin T 2011 The effect of melatonin against FK506-induced renal oxidative stress in rats. Surgical Innovation 18 34-38. (doi:10.1177/1553350610381088)

Aslaner A, Gunal O, Turgut HT, Celik E, Yildirim U, Demirci RK, Gunduz UR, Calis H \& Dogan S 2013 Effect of melatonin on kidney cold ischemic preservation injury. International Journal of Clinical and Experimental Medicine 6 794-798.

Aumente MD, Arizón JM, Segura J, López A, Albornoz R, Cárdenas M \& Segura C 2005 Relationship between pharmacokinetic parameters of cyclosporin and the incidence of acute rejection after heart transplantation. Transplantation Proceedings 37 4014-4017. (doi:10.1016/j.transproceed.2005.09.149)

Baan CC, Vaessen LM, Balk AH, Mochtar B, Jutte NH, Claas FH \& Weimar W 1994 Cyclosporin A sensitivity of allo-specific precursor and committed cytotoxic T lymphocytes after clinical heart transplantation. Transplantation Proceedings 26 2849-2851.

Badet L, Petruzzo P, Lefrançois N, McGregor B, Espa M, Berthillot C, Danjou F, Contu P, Aissa AH, Virieux SR, et al. 2005 Kidney preservation with IGL-1 solution: a preliminary report. Transplantation Proceedings 37 308-311. (doi:10.1016/ j.transproceed.2004.12.045)

Baines CP, Kaiser RA, Purcell NH, Blair NS, Osinska H, Hambleton MA, Brunskill EW, Sayen MR, Gottlieb RA, Dorn GW, et al. 2005 Loss of cyclophilin D reveals a critical role for mitochondrial permeability transition in cell death. Nature $\mathbf{4 3 4}$ 658-662. (doi:10.1038/ nature03434)

Barakat N, Hussein AA, Abdel-Maboud M, El-Shair MA, Mostafa A \& AbolEnein H 2010 Ischaemia-reperfusion injury in renal transplantation: the role of nitric oxide in an experimental rat model. BJU International 106 1230-1236. (doi:10.1111/j.1464-410X.2010.09225.x)

Barlow-Walden LR, Reiter RJ, Abe M, Pablos M, Menendez-Pelaez A, Chen LD \& Poeggeler B 1995 Melatonin stimulates brain glutathione

Published by Bioscientifica Ltd. 
peroxidase activity. Neurochemistry International 26 497-502. (doi:10.1016/0197-0186(94)00154-M)

Bejaoui M, Zaouali MA, Folch-Puy E, Pantazi E, Bardag-Gorce F, Carbonell T, Oliva J, Rimola A, Abdennebi HB \& Roselló-Catafau J 2014 Bortezomib enhances fatty liver preservation in Institut George Lopez-1 solution through adenosine monophosphate activated protein kinase and Akt/mTOR pathways. Journal of Pharmacy and Pharmacology 66 62-72. (doi:10.1111/jphp.12154)

Bejaoui M, Pantazi E, Folch-Puy E, Baptista PM, García-Gil A, Adam R \& Roselló-Catafau J 2015 Emerging concepts in liver graft preservation. World Journal of Gastroenterology 21 396-407. (doi:10.3748/wjg.v21. i2.396)

Belzer FO \& Southard JH 1988 Principles of solid-organ preservation by cold storage. Transplantation 45 673-676. (doi:10.1097/00007890198804000-00001)

Ben Mosbah I, Alfany-Fernandez I, Martel C, Zaouali MA, BintanelMorcillo M, Rimola A, Rodés J, Brenner C, Roselló-Catafau J \& Peralta C 2010 Endoplasmic reticulum stress inhibition protects steatotic and non-steatotic livers in partial hepatectomy under ischemia reperfusion. Cell Death \& Disease 1 e52. (doi:10.1038/ cddis.2010.29)

Besedovsky L, Lange T \& Born J 2012 Sleep and immune function. Pflugers Archiv 463 121-137. (doi:10.1007/s00424-011-1044-0)

Boros P \& Bromberg JS 2006 New cellular and molecular immune pathways in ischemia/reperfusion injury. American Journal of Transplantation 6 652-658. (doi:10.1111/j.16006143.2005.01228.x)

Bouma HR, Ketelaar ME, Yard BA, Ploeg RJ \& Henning RH 2010 AMP-activated protein kinase as a target for preconditioning in transplantation medicine. Transplantation 90 353-358. (doi:10.1097/ TP.0b013e3181e7a3aa)

Brismar K, Hylander B, Eliasson K, Rössner S \& Wetterberg L 1988 Melatonin secretion related to side-effects of beta-blockers from the central nervous system. Acta Medica Scandinavica 223 525-530.

Brougham MF \& Wallace WH 2005 Subfertility in children and young people treated for solid and haematological malignancies. British Journal of Haematology 131 143-155.

Burkhalter H, Wirz-Justice A, Denhaerynck K, Fehr T, Steiger J, Venzin RM, Cajochen C, Weaver TE \& De Geest S 2015 The effect of bright light therapy on sleep and circadian rhythms in renal transplant recipients: a pilot randomized, multicentre wait-list controlled trial. Transplant International 28 59-70. (doi:10.1111/tri.12443)

Buscemi N, Vandermeer B, Hooton N, Pandya R, Tjosvold L, Hartling L, Vohra S, Klassen TP \& Baker G 2006 Efficacy and safety of exogenous melatonin for secondary sleep disorders and sleep disorders accompanying sleep restriction: meta-analysis. British Medical Journal 332 385-393. (doi:10.1136/bmj.38731.532766.F6)

Calvo-Guirado JL, Gómez-Moreno G, Maté-Sánchez JE, López-Marí L, Delgado-Ruiz R \& Romanos GE 2015 New bone formation in bone defects after melatonin and porcine bone grafts: experimental study in rabbits. Clinical Oral Implants Research 26 399-406. (doi:10.1111/ clr.12364)

Cardell M, Jung FJ, Zhai W, Hillinger S, Welp A, Manz B, Weder W \& Korom S 2008 Acute allograft rejection and immunosuppression: influence on endogenous melatonin secretion. Journal of Pineal Research 44 261-266. (doi:10.1111/j.1600-079X.2007.00521.x)

Castanon-Cervantes O, Wu M, Ehlen JC, Paul K, Gamble KL, Johnson RL, Besing RC, Menaker M, Gewirtz AT \& Davidson AJ 2010 Dysregulation of inflammatory responses by chronic circadian disruption. Journal of Immunology 185 5796-5805. (doi:10.4049/ jimmunol.1001026)

Catena F, Coccolini F, Montori G, Vallicelli C, Amaduzzi A, Ercolani G, Ravaioli M, Del Gaudio M, Schiavina R, Brunocilla E, et al. 2013 Kidney preservation: review of present and future perspective. Transplantation Proceedings 45 3170-3177. (doi:10.1016/j. transproceed.2013.02.145)
Chavin KD, Fiorini RN, Shafizadeh SF, Cheng G, Wan C, Evans Z, Rodwell D, Polito C, Haines JK, Baillie GM, et al. 2004 Fatty acid synthase blockade protects steatotic livers from warm ischemia/ reperfusion injury and transplantation. American Journal of Transplantation 4 1440-1447. (doi:10.1111/j.1600-6143.2004.00546.x)

Cho YA, Noh K, Jue SS, Lee SY \& Kim EC 2015 Melatonin promotes hepatic differentiation of human dental pulp stem cells: clinical implications for the prevention of liver fibrosis. Journal of Pineal Research 58 127-135. (doi:10.1111/jpi.12198)

Codas R, Petruzzo P, Morelon E, Lefrançois N, Danjou F, Berthillot C, Contu P, Espa M, Martin X \& Badet L 2009 IGL-1 solution in kidney transplantation: first multi-center study. Clinical Transplantation 23 337-342. (doi:10.1111/j.1399-0012.2009.00959.x)

Coelho LA, Peres R, Amaral FG, Reiter RJ \& Cipolla-Neto J 2015 Daily differential expression of melatonin-related genes and clock genes in rat cumulus-oocyte complex: changes after pinealectomy. Journal of Pineal Research 58 490-499. (doi:10.1111/jpi.12234)

Cordoba J, Steindl P \& Blei AT 2009 Melatonin arrhythmia is corrected after liver transplantation. American Journal of Gastroenterology 104 1862-1863. (doi:10.1038/ajg.2009.171)

Crompton M 1999 The mitochondrial permeability transition pore and its role in cell death. Biochemical Journal 341 233-249. (doi:10.1042/ bj3410233)

De Perrot M, Liu M, Waddell T \& Keshavjee S 2003 Ischemia reperfusioninduced lung injury. American Journal of Respiratory and Critical Care Medicine 167 490-511. (doi:10.1164/rccm.200207-670SO)

Donderó F, Paugam-Burtz C, Danjou F, Stocco J, Durand F \& Belghiti J 2010 A randomized study comparing IGL-1 to the University of Wisconsin preservation solution in liver transplantation. Annals of Transplantation 15 7-14.

Erdogan H, Fadillioglu E, Yagmurca M, Ucar M \& Irmak MK 2006 Protein oxidation and lipid peroxidation after renal ischemia-reperfusion injury: protective effects of erdosteine and $\mathrm{N}$-acetylcysteine. Urological Research 34 41-46. (doi:10.1007/s00240-005-0031-3)

Ergüder IB, Cetin R, Devrim E, Kilicoglu B, Avci A \& Durak I 2005 Effects of cyclosporine on oxidant/antioxidant status in rat ovary tissues: protective role of black grape extract. International Immunopharmacology 5 1311-1315. (doi:10.1016/j. intimp.2005.03.016)

Ezzat H \& Mohab A 2015 Prevalence of sleep disorders among ESRD patients. Renal Failure 37 1013-1019. (doi:10.3109/08860 22X.2015.1044401)

Farrel GC, Teoh NC \& McCuskey RS 2008 Hepatic microcirculation in fatty liver disease. Anatomical Record 291 684-692. (doi:10.1002/ ar.20715)

Fildes JE, Yonan N \& Keevil BG 2009 Melatonin - a pleiotropic molecule involved in pathophysiological processes following organ transplantation. Immunology 127 443-449. (doi:10.1111/j.13652567.2009.03113.x)

Fisslthaler B \& Fleming I 2009 Activation and signaling by the AMPactivated protein kinase in endothelial cells. Circulation Research $\mathbf{1 0 5}$ 114-127. (doi:10.1161/CIRCRESAHA.109.201590)

Fitzpatrick E, Mitry RR \& Dhawan A 2009 Human hepatocyte transplantation: state of the art. Journal of Internal Medicine $\mathbf{2 6 6}$ 339-357. (doi:10.1111/j.1365-2796.2009.02152.x)

Francés D, Ronco MT, Ochoa E, Alvarez ML, Quiroga A, Parody JP, Monti J, Carrillo MC \& Carnovale CE 2007 Oxidative stress in primary culture hepatocytes isolated from partially hepatectomized rats. Canadian Journal of Physiology and Pharmacology 85 1047-1051. (doi:10.1139/Y07-087)

Freitas I, Bertone V, Guarnaschelli C, Ferrigno A, Boncompagni E, Rizzo V, Reiter RJ, Barni S \& Vairetti M 2006 In situ demonstration of improvement of liver mitochondria function by melatonin after cold ischemia. In Vivo 20 229-237.

Friedman O, Orvieto R, Fisch B, Felz C, Freud E, Ben-Haroush A \& Abir R 2012 Possible improvements in human ovarian grafting by

Published by Bioscientifica Ltd 
various host and graft treatments. Human Reproduction 27 474-482. (doi:10.1093/humrep/der385)

Frungieri MB, Mayerhofer A, Zitta K, Pignataro OP, Calandra RS \& Gonzalez-Calvar SI 2005 Direct effect of melatonin on Syrian hamster testes: melatonin subtype 1a receptors, inhibition of androgen production, and interaction with the local corticotropin-releasing hormone system. Endocrinology 146 1541-1552. (doi:10.1210/ en.2004-0990)

Galano A, Medina ME, Tan DX \& Reiter RJ 2015 Melatonin and its metabolites as copper chelating agents and their role in inhibiting oxidative stress: a physiochemical analysis. Journal of Pineal Research 58 107-116. (doi:10.1111/jpi.12196)

Gao S, Li P, Pan T \& Yang C 2003 Cardioprotective effects of melatonin on recovery of rat donor hearts after 12-hour preservation. Journal of Huazhong University of Science and Technology [Medical Sciences] 23 407-410. (doi:10.1007/BF02829430)

García JJ, López-Pingarrón L, Almeida-Souza P, Tres A, Escudero P, García-Gil FA, Tan DX, Reiter RJ, Ramírez JM \& Bernal-Pérez M 2014 Protective effects of melatonin in reducing oxidative stress and in preserving the fluidity of biological membranes: a review. Journal of Pineal Research 56 225-237. (doi:10.1111/jpi.12128)

Garcia-Gil FA, Gonzalvo E, Garcia-Garcia JJ, Albendea CD, Güemes A, Tome-Zelaya E, Fuentes L, Santa-Clotilde E, Aso J, Bejarano C, et al. 2006 Lipid peroxidation in ischemia-reperfusion oxidative injury of the graft preserved in Celsior and University of Wisconsin solutions on a pig pancreas transplantation model. Transplantation Proceedings 38 2595-2599. (doi:10.1016/j.transproceed.2006.08.030)

García-Gil FA, Albendea CD, Escartín J, Lampreave F, Fuentes-Broto L, Roselló-Catafau J, López-Pingarrón L, Reiter RJ, Alvarez-Alegret R \& García JJ 2011 Melatonin prolongs graft survival of pancreas allotransplants in pigs. Journal of Pineal Research $\mathbf{5 1} 445-453$. (doi:10.1111/j.1600-079x.2011.00908.x)

García-Gil FA, Albendea CD, López-Pingarrón L, Royo-Dachary P, Martínez-Guillén J, Piedrafita E, Martínez-Díez M, Soria J \& García JJ 2012 Altered cellular membrane fluidity levels and lipid peroxidation during experimental pancreas transplantation. Journal of Bioenergetics and Biomembranes 44 571-577. (doi:10.1007/s10863-012-9459-7)

Gholami M, Saki G, Hemadi M, Khodadadi A \& Mohammadi-Asl J 2014 Melatonin improves spermatogonial stem cells transplantation efficiency in azoospermic mice. Iranian Journal of Basic Medical Sciences 17 93-99.

Gill JS 2008 Cardiovascular disease in transplant recipients: current and future treatment strategies. Clinical Journal of the American Society of Nephrology 3 29-37. (doi:10.2215/CJN.02690707)

Grabb WC \& Dingman RO 1972 The fate of amputated tissues of the head and neck following replacement. Plastic and Reconstructive Surgery 48 28-32. (doi:10.1097/00006534-197201000-00005)

Green DR 2005 Apoptotic pathways: ten minutes to dead. Cell 121 671-674. (doi:10.1016/j.cell.2005.05.019)

Gruessner AC \& Sutherland DER 2005 Pancreas transplant outcomes for United States (US) and non-US cases as reported to the United Network for Organ Sharing (UNOS) and the International Pancreas Transplant Registry (IPTR) as of June 2004. Clinical Transplantation 19 433-455. (doi:10.1111/j.1399-0012.2005.00378.x)

Gu K, Kin S, Saitoh Y, Nosaka S, Sasaki T, Yamauchi M \& Nakayama K 1996 HTK solution is more effective than UW solution for cardiac preservation. Transplantation Proceedings 28 1906-1907.

Hardeland R 2005 Antioxidative protection by melatonin: multiplicity of mechanisms from radical detoxification to radical avoidance. Endocrine 27 119-130. (doi:10.1385/endo:27:2:119)

Hardeland R, Tan DX \& Reiter RJ 2009 Kynuramines, metabolites of melatonin and other indoles: the resurrection of an almost forgotten class of biogenic amines. Journal of Pineal Research 47 109-126. (doi:10.1111/j.1600-079x.2009.00701.x)

Hemadi M, Shokri S, Pourmatroud E, Moramezi F \& Khodadai A 2012 Follicular dynamic and immunoreactions of the vitrified ovarian graft after host treatment with variable regimens of melatonin. American Journal of Reproductive Immunology 67 401-412. (doi:10.1111/j.16000897.2011.01087.x)

Hemadi M, Shokri S, Moramezi F, Nikbakht R \& Sobhani A 2014 Potential use of melatonin supplementation to protect vitrified testicular grafts from hypoxic-ischaemic damage. Andrologia 46 513-521. (doi:10.1111/and.12110)

Henrich DE, Logan TC, Lewis RS \& Shockley WW 1995 Composite graft survival. An auricular amputation model. Archives of Otolaryngology - Head and Neck Surgery 121 1137-1142. (doi:10.1001/archo tol.1995.01890100049008)

Hines IN, Kawachi S, Harada H, Pavlick KP, Hoffman JM, Bharwani S, Wolf RE \& Grisham MB 2002 Role of nitric oxide in liver ischemia and reperfusion injury. Molecular and Cellular Biochemistry 234-235 229-237.

Hosepund JD, Bennet LE, Keck BM, Fiol B, Boucek MM \& Novick RJ 1999 The registry of the International Society for Heart and Lung Transplantation: sixteenth official report-1999. Journal of Heart and Lung Transplantation 18 611-626. (doi:10.1016/S10532498(99)00037-6)

Hsu CM, Wang JS, Liu CH \& Chen LW 2002 Kupffer cells protect liver from ischemia-reperfusion injury by an inducible nitric oxide synthase-dependent mechanism. Shock 17 280-285. (doi:10.1097/00024382-200204000-00007)

Huang Y, Rabb H \& Womer KL 2007 Ischemia-reperfusion and immediate T cell responses. Cellular Immunology 248 4-11. (doi:10.1016/j.cellimm.2007.03.009)

Hubert T, Gmyr V, Arnalsteen L, Jany T, Triponez F, Caiazzo R, Vandewalle B, Vantyghem MC, Kerr-Conte J \& Pattou F 2007 Influence of preservation solution on human islet isolation outcome. Transplantation 83 270-276. (doi:10.1097/01. tp.0000251723.97483.16)

Hui JM, Hodge A, Farrell GC, Kench JG, Kriketos A \& George J 2004 Beyond insulin resistance in NASH: TNF-alpha or adiponectin? Hepatology 40 46-54.

Inci I, Inci D, Dutly A, Boehler A \& Weder W 2002 Melatonin attenuates posttransplant lung ischemia-reperfusion injury. Annals of Thoracic Surgery 73 220-225. (doi:10.1016/S0003-4975(01)03101-0)

Ishkitiev N, Yaegaki K, Imai T, Tanaka T, Nakahara T, Ishikawa H, Mitev V \& Haapasalo M 2012 High-purity hepatic lineage differentiated from dental pulp stem cells in serum-free medium. Journal of Endodontics 38 475-480. (doi:10.1016/j.joen.2011.12.011)

Jaeschke H 1996 Preservation injury: mechanisms, prevention and consequences. Journal of Hepatology 25 774-780. (doi:10.1016/S01688278(96)80253-4)

Jaworek J \& Konturek SJ 2014 Hormonal protection in acute pancreatitis by ghrelin, leptin and melatonin. World Journal of Gastroenterology 20 16902-16912. (doi:10.3748/wjg.v20.i45.16902)

Jaworek J \& Leja-Szpak A 2014 Melatonin influences pancreatic cancerogenesis. Histology Histopathology 29 423-431.

Jiménez-Aranda A, Fernández-Vázquez G, Campos D, Tassi M, VelascoPérez L, Tan DX, Reiter RJ \& Agil A 2013 Melatonin induces browning of inguinal white adipose tissue in Zucker diabetic fatty rats. Journal of Pineal Research 55 416-423. (doi:10.1111/jpi.12089)

Jung FJ, Yang L, Härter L, Inci I, Schneiter D, Lardinois D, Keel M, Weder W \& Korom S 2004 Melatonin in vivo prolongs cardiac allograft survival in rats. Journal of Pineal Research 37 36-41.

Jung FJ, Yang L, De Meester I, Augustyns K, Cardell M, Hillinger S, Vogt P, Lardinois D, Scharpé S, Weder W, et al. 2006. CD26/ dipeptidylpeptidase IV-targeted therapy of acute lung rejection in rats. Journal of Heart and Lung Transplantation 25 1109-1116. (doi:10.1016/j.healun.2006.05.005)

Kanoria S, Glantzounis G, Quaglia A, Dinesh S, Fusai G, Davidson BR \& Seifalian AM 2012 Remote preconditioning improves hepatic oxygenation after ischaemia reperfusion injury. Transplant International 25 783-791. (doi:10.1111/j.1432-2277.2012.01481.x) 
Kapsimalis F, Basta M, Varouchakis G, Gourgoulianis K, Vgontzas A \& Kryger M 2008 Cytokines and pathological sleep. Sleep Medicine 9 603-614. (doi:10.1016/j.sleep.2007.08.019)

Kilic U, Kilic E, Reiter RJ, Bassetti CL \& Hermann DM 2005 Signal transduction pathways involved in melatonin-induced neuroprotection after focal cerebral ischemia in mice. Journal of Pineal Research 38 67-71. (doi:10.1111/j.1600-079x.2004.00178.x)

Kim SH \& Lee SM 2008 Cytoprotective effects of melatonin against necrosis and apoptosis induced by ischemia/reperfusion injury in rat liver. Journal of Pineal Research 44 165-171. (doi:10.1111/j.1600079x.2007.00504.x)

Kim Y, Turner D, Nelson J, Dobrinski I, McEntee M \& Travis AJ 2008 Production of donor-derived sperm after spermatogonial stem cell transplantation in the dog. Reproduction 136 823-831. (doi:10.1530/ REP-08-0226)

Kireev R, Bitoun S, Cuesta S, Tejerina A, Ibarrola C, Moreno E, Vara E \& Tresguerres JA 2013 Melatonin treatment protects liver of Zucker rats after ischemia/reperfusion by diminishing oxidative stress and apoptosis. European Journal of Pharmacology 701 185-193. (doi:10.1016/j.ejphar.2012.11.038)

Koc O, Gunduz B, Topcuoglu A, Bugdayci G, Yilmaz F \& Duran B 2010 Effects of pinealectomy and melatonin supplementation on endometrial explants in a rat model. European Journal of Obstetrics \& Gynecology and Reproduction Biology 153 72-76. (doi:10.1016/j.ejogrb.2010.06.012)

Korkmaz A, Reiter RJ, Topal T, Manchester LC, Oter S \& Tan DX 2009 Melatonin: an established antioxidant worthy of use in clinical trials. Molecular Medicine 15 43-50. (doi:10.2119/molmed.2008.00117)

Koyama H, Nakade O, Takada Y, Kaku T \& Lau KH 2002 Melatonin at pharmacologic doses increases bone mass by suppressing resorption through down-regulation of the RANKL-mediated osteoclast formation and activation. Journal of Bone and Mineral Research 17 1219-1229. (doi:10.1359/jbmr.2002.17.7.1219)

Kukan M \& Haddad PS 2001 Role of hepatocytes and bile duct cells in preservation-reperfusion injury of liver grafts. Liver Transplantation $\mathbf{7}$ 381-400. (doi:10.1053/jlts.2001.23913)

Kumar KV, Naidu MU, Shifow AA, Prayag A \& Ratnakar KS 1999 Melatonin: an antioxidant protects against cyclosporineinduced nephrotoxicity. Transplantation 67 1065-1068. (doi:10.1097/00007890-199904150-00022)

Lambeir AM, Durinx C, Scharpé S \& De Meester I 2003 Dipeptidylpeptidase IV from bench to bedside: an update on structural properties, functions, and clinical aspects of the enzyme DPP IV. Critical Reviews in Clinical Laboratory Sciences 40 209-294. (doi:10.1080/713609354)

Land WG 2005 The role of postischemic reperfusion injury and other nonantigen-dependent inflammatory pathways in transplantation. Transplantation 79 505-514. (doi:10.1097/01.TP.0000153160.82975.86)

Lang F, Busch GL, Zempel G, Ditlevsen J, Hoch M, Emerich U, Axel D, Fingerle J, Meierkord S, Apfel H, et al. $1995 \mathrm{Ca}^{2+}$ entry and vasoconstriction during osmotic swelling of vascular smooth muscle cells. Pflugers Archiv 431 253-258. (doi:10.1007/BF00410198)

Lass A, Akagbosu F \& Brinsden P 2001 Sperm banking and assisted reproduction treatment for couples following cancer treatment of the male partner. Human Reproduction Update 7 370-377. (doi:10.1093/ humupd/7.4.370)

Laudon M \& Frydman-Marom A 2014 Therapeutic effects of melatonin receptor agonists on sleep and comorbid disorders. International Journal of Molecular Sciences 15 15924-15950. (doi:10.3390/ ijms150915924)

Lee YM, Chen HR, Hsiao G, Sheu JR, Wang JJ \& Yen MH 2002 Protective effects of melatonin on myocardial ischemia/reperfusion injury in vivo. Journal of Pineal Research 33 72-80. (doi:10.1034/j.1600079x.2002.01869.x)

Li Z, Nickkholgh A, Yi X, Bruns H, Gross ML, Hoffmann K, Mohr E, Zorn M, Büchler MW \& Schemmer P 2009 Melatonin protects kidney grafts from ischemia/reperfusion injury through inhibition of NF-kB

http://joe.endocrinology-journals.org

DOI: $10.1530 / J O E-16-0117$
(C) 2016 Society for Endocrinology Printed in Great Britain and apoptosis after experimental kidney transplantation. Journal of Pineal Research 46 365-372. (doi:10.1111/j.1600-079x.2009.00672.x)

Li Y, Yang Y, Feng Y, Yan J, Fan C, Jiang S \& Qu Y 2014 A review of melatonin in hepatic ischemia/reperfusion injury and clinical liver disease. Annals of Medicine 46 503-511. (doi:10.3109/ 07853890.2014.934275)

Lim AA, Wall MP \& Greinwald JH Jr 1999 Effects of dimethylthiourea, melatonin, and hyperbaric oxygen therapy on the survival of reimplanted rabbit auricular composite grafts. Otolaryngology-Head and Neck Surgery 121 231-237. (doi:10.1016/S0194-5998(99)70177-4)

Lin GJ, Huang SH, Chen YW, Hueng DY, Chien MW, Chia WT, Chang DM \& Sytwu HK 2009 Melatonin prolongs islet graft survival in diabetic NOD mice. Journal of Pineal Research 47 284-292. (doi:10.1111/j.1600-079x.2009.00712.x)

Liu C, Hong T, Shao M, Chen Z \& Wang C 2014 Melatonin synergized with cyclosporine A improves cardiac allograft survival by suppressing inflammation and apoptosis. Molecular Medicine Reports 10 1323-1328. (doi:10.3892/mmr.2014.2382)

Loong CC, Chang YH, Wu TH, King KL, Yang WC, Wu CW \& Lui WY 2004 Antioxidant supplementation may improve renal transplant function: a preliminary report. Transplantation Proceedings $\mathbf{3 6}$ 2438-2439. (doi:10.1016/j.transproceed.2004.06.053)

Lutz J, Thürmel K \& Hermann U 2010 Anti-inflammatory treatment strategies for ischemia/reperfusion injury in transplantation. Journal of Inflammation 727.

Manchester LC, Coto-Montes A, Boga JA, Andersen LP, Zhou Z, Galano A, Vriend J, Tan DX \& Reiter RJ 2015 Melatonin: an ancient molecule that makes oxygen metabolically tolerable. Journal of Pineal Research 59 403-419. (doi:10.1111/jpi.12267)

Mangus RS, Fridell JA, Vianna RM, Milgrom MA, Chestovich P, Chihara RK \& Tector AJ 2008 Comparison of histidine-tryptophanketoglutarate solution and University of Wisconsin solution in extended criteria liver donors. Liver Transplantation 14 365-373. (doi:10.1002/lt.21372)

Maria S \& Witt-Enderby PA 2014 Melatonin effects on bone: potential use for the prevention and treatment for osteopenia, osteoporosis, and periodontal disease and for use in bone-grafting procedures. Journal of Pineal Research 56 115-125. (doi:10.1111/jpi.12116)

Matsui Y, Kyoi S, Takagi H, Hsu CP, Hariharan N, Ago T, Vatner SF \& Sadoshima J 2008 Molecular mechanisms and physiological significance of autophagy during myocardial ischemia and reperfusion. Autophagy 4 409-415. (doi:10.4161/auto.5638)

Menasché P, Termignon JL, Pradier F, Grousset C, Mouas C, Alberici G, Weiss M, Piwnica A \& Bloch G 1994 Experimental evaluation of Celsior, a new heart preservation solution. European Journal of Cardiothoracic Surgery 8 207-213. (doi:10.1016/1010-7940(94)90117-1)

Middleton B 2006 Measurement of melatonin and 6-sulphatoxymelatonin. Methods in Molecular Biology 324 235-254.

Mikkola M, Sironen A, Kopp C, Taponen J, Sukura A, Vilkki J, Katila T \& Andersson M 2006 Transplantation of normal boar testicular cells resulted in complete focal spermatogenesis in a boar affected by the immotile short-tail sperm defect. Reproduction in Domestic Animals 41 124-128. (doi:10.1111/j.1439-0531.2006.00651.x)

Mohammadghasemi F, Faghani M \& Khajeh S 2010 The protective effects of melatonin on the histological changes of testis in busulfan-treated adult mice. Journal of Reproduction \& Infertility 11 67-76.

Morales-Indiano C, Lauzurica R, Pastor MC, Bayés B, Sancho A, Troya M \& Romero R 2009 Greater posttransplant inflammation and oxidation are associated with worsening kidney function in patients with pretransplant diabetes mellitus. Transplantation Proceedings 41 2126-2128. (doi:10.1016/j.transproceed.2009.06.032)

Moussavian MR, Scheuer C, Schmidt M, Kollmar O, Wagner M, von Heesen M, Schilling MK \& Menger MD 2011 Multidrug donor preconditioning prevents cold liver preservation and reperfusion injury. Langenbecks Archives of Surgery 396 231-241. (doi:10.1007/ s00423-010-0668-4) 
Muñoz-Casares FC, Padillo FJ, Briceño J, Collado JA, MuñozCastañeda JR, Ortega R, Cruz A, Túnez I, Montilla P, Pera C, et al. 2006 Melatonin reduces apoptosis and necrosis induced by ischemia/ reperfusion injury of the pancreas. Journal of Pineal Research $\mathbf{4 0}$ 195-203. (doi:10.1111/j.1600-079x.2005.00291.x)

Negre-Salvayre A, Auge N, Ayala V, Basaga H, Boada J, Brenke R, Chapple S, Cohen G, Feher J, Grune T, et al. 2010 Pathological aspects of lipid peroxidation. Free Radical Research 44 1125-1171. (doi:10.310 9/10715762.2010.498478)

Nugent D, Newton H, Gallivan L \& Gosden RG 1998 Protective effect of vitamin E on ischaemia-reperfusion injury in ovarian grafts. Journal of Reproduction \& Fertility 114 341-346.

Okatani Y, Wakatsuki A, Reiter RJ, Enzan H \& Miyahara Y 2003 Protective effect of melatonin against mitochondrial injury induced by ischemia and reperfusion of rat liver. European Journal of Pharmacology 469 145-152. (doi:10.1016/S0014-2999(03)01643-1)

Orwig KE \& Schlatt S 2005 Cryopreservation and transplantation of spermatogonia and testicular tissue for preservation of male fertility. Journal of the National Cancer Institute Monographs 51-56. (doi:10.1093/jncimonographs/lgi029)

Ostrowska Z, Ziora K, Kos-Kudła B, Swietochowska E, Oswiecimska J, Dyduch A, Wołkowska-Pokrywa K \& Szapska B 2010 Melatonin, the RANKL/RANK/OPG system, and bone metabolism in girls with anorexia nervosa. Endokrynologia Polska 61 117-123.

Pablos MI, Reiter RJ, Ortiz GG, Guerrero JM, Agapito MT, Chuang JI \& Sewerynek E 1998 Rhythms of glutathione peroxidase and glutathione reductase in brain of chick and their inhibition by light. Neurochemistry International 32 69-75. (doi:10.1016/S0197-0186(97)00043-0)

Padrissa-Altés S, Zaouali MA, Bartrons R \& Roselló-Catafau J 2012 Ubiquitin-proteasome system inhibitors and AMPK regulation in hepatic cold ischaemia and reperfusion injury: possible mechanisms. Clinical Science 123 93-98. (doi:10.1042/CS20110093)

Pappolla MA, Chyan YJ, Poeggeler B, Bozner P, Ghiso J, Le Doux SP \& Wilson GL 1999 Alzheimer h protein mediated oxidative damage to mitochondrial DNA: prevention by melatonin. Journal of Pineal Research 27 226-229. (doi:10.1111/j.1600-079x.1999.tb00619.x)

Pawlak K, Pawlak D \& Mysliwiec M 2007 Impaired renal function and duration of dialysis therapy are associated with oxidative stress and proatherogenic cytokine levels in patients with end-stage renal disease. Clinical Biochemistry 40 81-85. (doi:10.1016/ j.clinbiochem.2006.09.001)

Petrowsky H \& Clavien PA 2014 Principles of liver transplantation. In Transplantation of the Liver, edn 3 pp 582-600. Eds R Bulsuttil \& G Klintmalm. Philadelphia, PA, USA: Elsevier Saunders.

Pinto AR, da Silva NC \& Pinato L 2016 Analyses of melatonin, cytokines, and sleep in chronic renal failure. Sleep and Breathing 20 339-344. (doi:10.1007/s11325-015-1240-9)

Puhl G, Olschewski P, Schoning W, Hunold G, Liesaus HG, Winkler R, Neumann UP, Schubert TE, Schmitz V \& Neuhaus P 2006 Low viscosity histidine-tryptophan-ketoglutarate graft flush improves subsequent extended cold storage in University of Wisconsin solution in an extracorporeal rat liver perfusion and rat liver transplantation model. Liver Transplantation 12 1841-1849. (doi:10.1002/lt.20913)

Quiroz Y, Ferrebuz A, Romero F, Vaziri ND \& Rodriguez-Iturbe B 2008 Melatonin ameliorates oxidative stress, inflammation, proteinuria, and progression of renal damage in rats with renal mass reduction. American Journal of Physiology: Renal Physiology 294 336-344.

Ramalho FS, Fernandez-Monteiro I, Rosello-Catafau J \& Peralta C 2006 Hepatic microcirculatory failure. Acta Cirurgica Brasileira 21 48-53. (doi:10.1590/S0102-86502006000700012)

Ramella-Virieux SG, Steghens JP, Barbieux A, Zech P, Pozet N \& Hadj-Aïssa A 1997 Nifedipine improves recovery function of kidneys preserved in a high-sodium, low-potassium cold-storage solution: study with the isolated perfused rat kidney technique. Nephrology Dialysis Transplantation 12 449-455. (doi:10.1093/ ndt/12.3.449)
Reed JC 1994 Bcl-2 and the regulation of programmed cell death. Journal of Cell and Biology 124 1-6. (doi:10.1083/jcb.124.1.1)

Reichenspurner H, Russ C, Uberfuhr P, Nollert G, Schlüter A, Reichart B, Klövekorn WP, Schüler S, Hetzer R, Brett W, et al. 1993 Myocardial preservation using HTK solution for heart transplantation. A multicenter study. European Journal of Cardiothoracic Surgery 7 414-419. (doi:10.1016/1010-7940(93)90005-V)

Reiter RJ, Tan DX, Osuna C \& Gitto E 2000 Actions of melatonin in the reduction of oxidative stress: a review. Journal of Biomedical Science $\mathbf{7}$ 444-458. (doi:10.1007/BF02253360)

Reiter RJ, Paredes SD, Manchester LC \& Tan DX 2009a Reducing oxidative/nitrosative stress: a newly-discovered genre for melatonin. Critical Reviews in Biochemistry and Molecular Biology 44 175-200.

Reiter RJ, Tan DX, Manchester LC, Paredes SD, Mayo JC \& Sainz RM $2009 \mathrm{~b}$ Melatonin and reproduction re-visited. Biology of Reproduction $81445-456$.

Reiter RJ, Tan DX \& Fuentes-Broto L 2010 Melatonin: a multitasking molecule. Progress in Brain Research 181 127-151. (doi:10.1016/S00796123(08)81008-4)

Reiter RJ, Rosales-Corral SA, Manchester LC \& Tan DX 2013 Peripheral reproductive organ health and melatonin: ready for prime time. International Journal of Molecular Science 14 7231-7272. (doi:10.3390/ ijms14047231)

Reiter RJ, Tan DX, Rosales-Corral SD \& Manchester LC 2014 The universal nature, unequal distribution and antioxidant function of melatonin and its derivatives. Mini-Reviews in Medicinal Chemistry 13 373-384.

Rodriguez C, Mayo JC, Sainz RM, Antolín I, Herrera F, Martín V \& Reiter RJ 2004 Regulation of antioxidant enzymes: a significant role for melatonin. Journal of Pineal Research 36 1-9. (doi:10.1046/j.1600079X.2003.00092.x)

Rodriguez-Reynoso S, Leal C, Portilla E, Olivares N \& Muniz J 2001 Effect of exogenous melatonin on hepatic energetic status during ischemia/ reperfusion: possible role of tumor necrosis factor- $\alpha$ and nitric oxide. Journal of Surgical Research 100 141-149. (doi:10.1006/jsre.2001.6185)

Romero A, Ramos E, de Los Rios C, Egea J, del Pino J \& Reiter RJ 2014 A review of metal-catalyzed molecular damage: protection by melatonin. Journal of Pineal Research 56 343-370. (doi:10.1111/jpi.12132)

Roth JA, Kim BG, Lin WL \& Cho MI 1999 Melatonin promotes osteoblast differentiation and bone formation. Journal of Biological Chemistry 274 22041-22047. (doi:10.1074/jbc.274.31.22041)

Rudd DM \& Dobson GP 2011 Eight hours of cold static storage with adenosine and lidocaine (adenocaine) heart preservation solutions: toward therapeutic suspended animation. Journal of Thoracic and Cardiovascular Surgery 142 1552-1561. (doi:10.1016/j. jtcvs.2011.05.023)

Russcher M, Nagtegaal JE, Nurmohamed SA, Koch BC, van der Westerlaken MM, van Someren EJ, Bakker SJ, Ter Wee PM \& Gaillard CA 2015 The effects of kidney transplantation on sleep, melatonin, circadian rhythm and quality of life in kidney transplant recipients and living donors. Nephron 129 6-15. (doi:10.1159/000369308)

Salehi P, Hansen MA, Avila JG, Barbaro B, Gangemi A, Romagnoli T, Wang Y, Qi M, Murdock P, Benedetti E, et al. 2006 Human islet isolation outcomes from pancreata preserved with HistidineTryptophan Ketoglutarate versus University of Wisconsin solution. Transplantation 82 983-985.

Santana-Rodríguez N, Clavo B, Llontop P, López A, García-Castellano JM, Machín RP, Ponce MA, Fiuza MD, García-Herrera R, Brito Y, et al . 2011 Estradiol worsens the syndrome of ischemia-reperfusion injury in an experimental lung transplantation model. Lung 189 251-255. (doi:10.1007/s00408-011-9287-2)

Sapmaz E, Ayar A, Celik H, Sapmaz T, Kilic N \& Yasar MA 2003 Effects of melatonin and oxytetracycline in autologous intraperitoneal ovary transplantation in rats. Neuroendocrinology Letters 24 350-354.

Scheinichen D, zu Vilsendorf AM, Weissig A, Bornscheuer A, Becker T, Juettner B, Mahr KH \& Heine J 2003 Reduced P-selectin expression

Published by Bioscientifica Ltd. 
on circulating platelets after prolonged cold preservation in renal transplantation. Clinical Transplantation 17 444-450. (doi:10.1034/ j.1399-0012.2003.00073.x)

Selzner M \& Clavien P 2001 Fatty liver in liver transplantation and surgery. Seminars in Liver Disease 21 105-113.

Serracino-Inglott F, Habib NA \& Mathie RT 2001 Hepatic ischemiareperfusion injury. American Journal of Surgery 181 160-166. (doi:10.1016/S0002-9610(00)00573-0)

Shah V \& Kamath PS 2003 Nitric oxide in liver transplantation: pathobiology and clinical implications. Liver Transplantation 9 1-11. (doi:10.1053/jlts.2003.36244)

Shaw BW Jr 1995 Auxiliary liver transplantation for acute liver failure. Liver Transplantation and Surgery 1 194-200. (doi:10.1002/ 1t.500010311)

Simmons EM, Langone A, Sezer MT, Vella JP, Recupero P, Morrow JD, Ikizler TA \& Himmelfarb J 2005 Effect of renal transplantation on biomarkers of inflammation and oxidative stress in end-stage renal disease patients. Transplantation 79 914-919. (doi:10.1097/01. ТР.0000157773.96534.29)

Singh M \& Jadhav HR 2014 Melatonin: functions and ligands. Drug Discovery Today 19 1410-1418. (doi:10.1016/j.drudis.2014.04.014)

Smets F, Najimi M \& Sokal EM 2008 Cell transplantation in the treatment of liver diseases. Pediatric Transplantation 12 6-13. (doi:10.1111/ j.1399-3046.2007.00788.x)

Solanas E, Sostres C, Serrablo A, García-Gil A, García JJ, Aranguren FJ, Jiménez P, Hughes RD \& Serrano MT 2015 Effect of Dimethyl Sulfoxide and Melatonin on the isolation of human primary hepatocytes. Cells Tissues Organs 200 316-325. (doi:10.1159/000433521)

Southard JH 1997 Improving early graft function: role of preservation. Transplantation Proceedings 29 3510-3511. (doi:10.1016/S00411345(97)00999-8)

Stewart SF, Vidali M, Day CP, Albano E \& Jones DEJ 2004 Oxidative stress as a trigger for cellular immune response in patients with alcoholic liver disease. Hepatology 39 197-203. (doi:10.1002/ hep.20021)

Stringham JC, Southard JH, Hegge J, Triemstra L, Fields BL \& Belzer FO 1992 Limitations of heart preservation by cold storage. Transplantation 53 287-294. (doi:10.1097/00007890-19920201000007)

Swanson DK, Pasaoglu I, Berkoff HA, Southard JA \& Hegge JO 1988 Improved heart preservation with UW preservation solution. Journal of Heart Transplantation 7 456-467.

Takechi M, Tatehara S, Satomura K, Fujisawa K \& Nagayama M 2008 Effect of FGF-2 and melatonin on implant bone healing: a histomorphometric study. Journal of Materials Science: Materials in Medicine 19 2949-2952. (doi:10.1007/s10856-008-3416-3)

Tamura H, Nakamura Y, Korkmaz A, Manchester LC, Tan DX, Sugino N \& Reiter RJ 2009 Melatonin and the ovary: physiological and pathophysiological implications. Fertility and Sterility 92 328-343. (doi:10.1016/j.fertnstert.2008.05.016)

Tan DX, Chen LD, Poeggeler B, Manchester LC \& Reiter RJ 1993 Melatonin: a potent, endogenous hydroxyl radical scavenger. Endocrine Journal 1 57-60.

Tan DX, Manchester LC, Reiter RJ, Qi WB, Zhang M, Weintraub ST, Cabrera J, Sainz RM \& Mayo JC 1999 Identification of highly elevated levels of melatonin in bone marrow: its origin and significance. Biochimica et Biophysica Acta 1472 206-214. (doi:10.1016/S03044165(99)00125-7)

Teoh NC \& Farrell GC 2003 Hepatic ischemia reperfusion injury: pathogenic mechanisms and basis for hepatoprotection. Journal of Gastroenterology and Hepatology 18 891-902. (doi:10.1046/j.14401746.2003.03056.x)

Tresguerres JA, Cuesta S, Kireev RA, Garcia C, Acuña-Castroviejo D \& Vara E 2013 Beneficial effect of melatonin treatment on age-related insulin resistance and on the development of type 2 diabetes.
Hormone Molecular Biology and Clinical Investigation 16 47-54. (doi:10.1515/hmbci-2013-0041)

Turgut M, Yenisey C, Uysal A, Bozkurt M \& Yurtseven ME 2003 The effects of pineal gland transplantation on the production of spinal deformity and serum melatonin level following pinealectomy in the chicken. European Spine Journal 12 487-494. (doi:10.1007/s00586-0030528-9)

Vairetti M, Ferrigno A, Bertone R, Rizzo V, Richelmi P, Bertè F, Reiter RJ \& Freitas I 2005 Exogenous melatonin enhances bile flow and ATP levels after cold storage and reperfusion in rat liver: implications for liver transplantation. Journal of Pineal Research 38 223-230. (doi:10.1111/ j.1600-079x.2004.00193.x)

Vajdic CM, McDonald SP, McCredie MR, van Leeuwen MT, Stewart JH, Law M, Chapman JR, Webster AC, Kaldor JM \& Grulich AE 2006 Cancer incidence before and after kidney transplantation. JAMA 296 2823-2831. (doi:10.1001/jama.296.23.2823)

Venegas C, Garcia JA, Escames G, Ortiz F, Lopez A, Doerrier C, GarciaCorzo L, Lopez LC, Reiter RJ \& Acuna-Castroviejo D 2012 Extrapineal melatonin: analysis of its subcellular distribution and daily fluctuations. Journal of Pineal Research 52 217-227. (doi:10.1111/ j.1600-079x.2011.00931.x)

Viollet B, Foretz M, Guigas B, Horman S, Dentin R, Bertrand L, Hue L \& Andreelli F 2006 Activation of AMP-activated protein kinase in the liver: a new strategy for the management of metabolic hepatic disorders. Journal of Physiology $\mathbf{5 7 4}$ 41-53. (doi:10.1113/jphysiol.2006.108506)

von Heesen M, Hülser M, Seibert K, Scheuer C, Dold S, Kollmar O, Wagner M, Menger MD, Schilling MK \& Moussavian MR 2011 Split-liver procedure and inflammatory response: improvement by pharmacological preconditioning. Journal of Surgical Research $\mathbf{1 6 8}$ 125-135. (doi:10.1016/j.jss.2011.01.036)

von Heesen M, Seibert K, Hülser M, Scheuer C, Wagner M, Menger MD, Schilling MK \& Moussavian MR 2012 Multidrug donor preconditioning protects steatotic liver grafts against ischemiareperfusion injury. American Journal of Surgery 203 168-176. (doi:10.1016/j.amjsurg.2011.01.026)

Vriend J \& Reiter R J2014a Melatonin as a proteasome inhibitor. Is there any clinical evidence? Life Science 115 8-14.

Vriend J \& Reiter RJ 2014b Melatonin and ubiquitin: what's the connection? Cellular and Molecular Life Sciences 71 3409-3418.

Vriend J \& Reiter RJ 2015 Melatonin feedback on clock genes: a theory involving the proteasome. Journal of Pineal Research 58 1-11. (doi:10.1111/jpi.12189)

Vural A, Yilmaz MI, Caglar K, Aydin A, Sonmez A, Eyileten T, Acikel C, Gulec B, Kozak O \& Oner K 2005 Assessment of oxidative stress in the early posttransplant period: comparison of cyclosporine A and tacrolimus-based regimens. American Journal of Nephrology $\mathbf{2 5}$ 250-255. (doi:10.1159/000086079)

Wang WZ, Fang XH, Stephenson LL, Baynosa RC, Khiabani KT \& Zamboni WA 2005 Microcirculatory effects of melatonin in rat skeletal muscle after prolonged ischemia. Journal of Pineal Research 39 57-65. (doi:10.1111/j.1600-079x.2005.00215.x)

Wang JH, Ahn IS, Fischer TD, Byeon JI, Dunn WA Jr, Behrns KE, Leeuwenburgh C \& Kim JS 2011 Autophagy suppresses age-dependent ischemia and reperfusion injury in livers of mice. Gastroenterology $\mathbf{1 4 1}$ 2188-2199. (doi:10.1053/j.gastro.2011.08.005)

Witzigmann H, Ludwig S, Armann B, Gäbel G, Teupser D, Kratzsch J, Pietsch UC, Tannapfel A, Geissler F, Hauss J, et al. 2003 Endothelin(A) receptor blockade reduces ischemia/reperfusion injury in pig pancreas transplantation. Annals of Surgery 238 264-274.

Wullstein C, Drognitz O, Woeste G, Schareck WD, Bechstein WO, Hopt UT \& Benz S 2004 High levels of C-reactive protein after simultaneous pancreas-kidney transplantation predict pancreas graftrelated complications and graft survival. Transplantation $\mathbf{7 7}$ 60-64. (doi:10.1097/01.TP.0000100683.92689.27)

Xiaodong Y \& Ashok JT 2010 Machine perfusion or cold storage in organ transplantation: indication, mechanisms, and future

Published by Bioscientifica Ltd 
prospective. Transplant International 23 561-570. (doi:10.1111/ j.1432-2277.2009.01047.x)

Yang Q \& He GW 2005 Effect of cardioplegic and organ preservation solutions and their components on coronary endothelium-derived relaxing factors. Annals of Thoracic Surgery 80 757-767. (doi:10.1016/j. athoracsur.2004.10.003)

Yellon DM \& Hausenloy DJ 2007 Myocardial reperfusion injury. New England Journal of Medicine 357 1121-1135. (doi:10.1056/ NEJMra071667)

Zaouali MA, Ben Abdennebi H, Padrissa-Altés S, Mahfoudh-Boussaid A \& Roselló-Catafau J 2010a Pharmacological strategies against cold ischemia reperfusion injury. Expert Opinion on Pharmacotherapy 11 537-555. (doi:10.1517/14656560903547836)

Zaouali MA, Padrissa-Altés S, Ben Mosbah I, Ben Abdennebi H, Boillot O, Rimola A, Saidane-Mosbahi D \& Catafau J 2010 $b$ Insulin like growth factor-1 increases fatty liver preservation in IGL-1 solution. World Journal of Gastroenterology 16 5693-5700.

Zaouali MA, Ben Mosbah I, Boncompagni E, Ben Abdennebi $\mathrm{H}$ Mitjavila MT, Bartrons R, Freitas I, Rimola A \& Roselló-Catafau J 2010 c Hypoxia inducible factor-1alpha accumulation in steatotic liver preservation: role of nitric oxide. World Journal of Gastroenterology 16 3499-3509.

Zaouali MA, Bardag-Gorce F, Carbonell T, Oliva J, Pantazi E, Bejaoui M, Ben Abdennebi H, Rimola A \& Roselló-Catafau J 2013a Proteasome inhibitors protect the steatotic and non-steatotic liver graft against cold ischemia reperfusion injury. Experimental and Molecular Pathology 94 352-359. (doi:10.1016/j.yexmp.2012.12.005)

Zaouali MA, Boncompagni E, Reiter RJ, Bejaoui M, Freitas I, Pantazi E, Folch-Puy E, Abdennebi HB, Garcia-Gil FA \& Roselló-Catafau J $2013 b$ AMPK involvement in endoplasmic reticulum stress and autophagy modulation after fatty liver graft preservation: a role for melatonin and trimetazidine cocktail. Journal of Pineal Research 55 65-78. (doi:10.1111/jpi.12051)

Zhai W, Cardell M, De Meester I, Augustyns K, Hillinger S, Inci I, Arni S, Jungraithmayr W, Scharpé S, Weder W, et al. 2007 Intragraft DPP IV inhibition attenuates post-transplant pulmonary ischemia/ reperfusion injury after extended ischemia. Journal of Heart and Lung Transplantation 26 174-180. (doi:10.1016/j.healun.2006.11.601)

Zhai W, Jungraithmayr W, De Meester I, Inci I, Augustyns K, Arni S, Hillinger S, Scharpé S, Weder W \& Korom S 2009 Primary graft dysfunction in lung transplantation: the role of CD26/ dipeptidylpeptidase IV and vasoactive intestinal peptide. Transplantation 27 1140-1146. (doi:10.1097/TP.0b013e31819e04c3)

Zhai Y, Busuttil WR \& Kupiec-Weglinski WJ 2011 Liver ischemia and reperfusion injury: new insights into mechanisms of innateadaptive immune-mediated tissue inflammation. American Journal of Transplantation 11 1563-1569. (doi:10.1111/j.1600-6143.2011.03579.x)

Zhang HM \& Zhang Y 2014 Melatonin: a well-documented antioxidant with conditional pro-oxidant actions. Journal of Pineal Research $\mathbf{5 7}$ 131-146. (doi:10.1111/jpi.12162)

Received in final form 6 April 2016

Accepted 11 April 2016

Accepted Preprint published online 11 April 2016
(C) 2016 Society for Endocrinology Printed in Great Britain
Published by Bioscientifica Ltd. 